Journal of

Psychopharmacology

\title{
An exploratory study of information sources and key findings on UK cocaine-related deaths
}

\begin{tabular}{|c|c|}
\hline Journal: & Journal of Psychopharmacology \\
\hline Manuscript ID & JOP-2016-3006.R1 \\
\hline Manuscript Type: & Original Paper \\
\hline Date Submitted by the Author: & $\mathrm{n} / \mathrm{a}$ \\
\hline Complete List of Authors: & $\begin{array}{l}\text { Corkery, John; University of Hertfordshire, Pharmacy, Pharmacology \& } \\
\text { Postgraduate Medicine } \\
\text { Claridge, Hugh; St George's University of London, National Programme on } \\
\text { Substance Abuse Deaths } \\
\text { Goodair, Christine; St George's University of London, National Programme } \\
\text { on Substance Abuse Deaths } \\
\text { Schifano, Fabrizio; University of Hertfordshire, Department of Pharmacy, } \\
\text { Pharmacology \& Postgraduate Medicine }\end{array}$ \\
\hline $\begin{array}{r}\text { Please list at least } 3 \text { keywords } \\
\text { which relate to your } \\
\text { manuscript: }\end{array}$ & $\begin{array}{l}\text { Cocaine deaths, data sources, characteristics, investigation, United } \\
\text { Kingdom (UK) }\end{array}$ \\
\hline Abstract: & $\begin{array}{l}\text { Cocaine-related deaths have increased since the early } 1990 \text { in Europe, } \\
\text { including the UK. Being multi-factorial, they are difficult to define, detect } \\
\text { and record. The European Monitoring Centre for Drugs \& Drug Addiction } \\
\text { (EMCDDA) commissioned research to: describe trends reported to Special } \\
\text { Mortality Registries (SMRs) and General Mortality Registers (GMRs); } \\
\text { provide demographic and drug-use characteristic information of cases; and } \\
\text { establish how deaths are identified and classified. A questionnaire was } \\
\text { developed and piloted amongst all EMCDDA Focal Point experts/SMRs: } 19 \\
\text { (63\%) responded; nine countries provided aggregated data. UK GMRs use } \\
\text { cause of death and toxicology to identify cocaine-related deaths. } \\
\text { Categorisation is based on International Classification of Diseases (ICD) } \\
\text { codes. SMRs use toxicology, autopsy, evidence and cause of death. The } \\
\text { cocaine metabolites commonly screened for are: benzoylecgonine, } \\
\text { ecgonine methyl ester, cocaethylene and ecgonine. The } 2000 \text { s saw a } \\
\text { generally accelerating upward trend in cases, followed by a decline in } \\
2009 \text {. The UK recorded } 2700-2900 \text { deaths during } 1998-2012 \text {. UK SMR data } \\
\text { (2005-9) indicate: } 25-44 \text { year-olds account for } 74 \% \text { of deaths; mean age } \\
=34 \text { (range } 15-81 \text { ) years; } 84 \% \text { male. Cocaine overdoses account for two- } \\
\text { thirds of cases; cocaine alone being mentioned/implicated in } 23 \% \text { in the } \\
\text { UK. Opioids are involved in most (58\%) cocaine overdose cases. }\end{array}$ \\
\hline
\end{tabular}




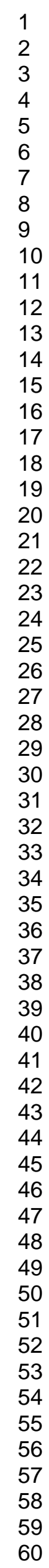

SCHOLARONE $^{\text {th }}$

Manuscripts

http://mc.manuscriptcentral.com/jop 
An exploratory study of information sources and key findings on UK cocaine-related deaths

John Martin Corkery ${ }^{1}$ Hugh Claridge $^{2}$, Christine Goodair $^{2}$ and Fabrizio Schifano ${ }^{1}$

1 Psychopharmacology, Drug Misuse and Novel Psychoactive Substances Research Unit, University of Hertfordshire, UK

2 National Programme on Substance Abuse Deaths, St George's University of London, UK

\section{Corresponding author:}

John M. Corkery

Department of Pharmacy, Pharmacology \& Post-Graduate Medicine

University of Hertfordshire

Health Research Building

College Lane Campus

Hatfield, Herts.

AL10 9AB, United Kingdom.

Email: j.corkery@herts.ac.uk 
An exploratory study of information sources and key findings on UK cocaine-related deaths

Word count: [7525 $\Rightarrow>7672]$

\section{Glossary}

ATS Amphetamine-type stimulants

COD Cause of death

DRD Drug-related death

EMCDDA European Monitoring Centre for Drugs and Drug Addiction

GHB/GBL Gammahydroxybutyrate/Gammabutyrolactone

GMR General Mortality Register

ICD-10 International Classification of Diseases and Related Health Problems 10th

Revision

'Legal highs' Licit drugs (chiefly stimulants such as cathinones, synthetic cannabinoids, etc.

which may or may not have become regulated/controlled during the time-period examined by this project)

MDMA Methylenedioxymethylamphetamine

NFP National Focal Point

NPS Novel Psychoactive Substances

NPSAD National Programme on Substance Abuse Deaths

PM post mortem (autopsy)

SMR Special Mortality Registry

UK United Kingdom 


\section{Introduction}

There has been increasing prevalence of cocaine use in some countries, and indications of increased number of cocaine deaths in some European countries up to the end of the first decade of the present century (in excess of 1,000 in 2007-8). Deaths were still at high levels in 2011, at least 475 deaths in 17 countries, (EMCDDA, 2011; 2013a, 2013c), and at least 800 were reported from 27 countries in 2013 (EMCDDA, 2015:45). In addition, there is evidence of a considerable burden of morbidity related to cocaine use in Europe (Mena et al., 2013;

EMCDDA, 2013b, 2014). High mortality among cocaine users has been documented in different parts of the world, including Europe (Degenhardt et al., 2011; Barrio et al., 2013; Pavarin, 2013; de la Fuente et al., 2014).

In the wider context, other factors have been shown to be related to cocaine-related deaths, these include a: positive correlation with 'last year' use of cocaine powder, number of offenders, and number of seizures, but negatively with price (Schifano and Corkery, 2008). Furthermore, such deaths are correlated positively with the numbers of crack offenders and seizures, but negatively with crack purity and price.

Cocaine-related deaths are underestimated as they are more difficult to define, detect and record as such in mortality registries compared to, for instance, to heroin-related deaths - more particularly in some countries' General Mortality Registers (GMRs) due to coding practices. The characteristics of cocaine deaths are multi-factorial (socio-demographics, toxicology, circumstances and mechanism of death), and are often different from opiate/opioid deaths and may not be collected by GMRs (Corkery, 2012; EMCDDA, 2013a). 
A project was commissioned to provide better information on the numbers and characteristics of cocaine-related deaths in Europe, to complete and deepen the information usually provided on drug overdose deaths (drug-induced deaths) to the European Monitoring Centre for Drugs \& Drug Addiction (EMCDDA, 2010). This element complements the current routine data collection on drug-induced deaths by the EMCDDA, which provides only limited information on cocainerelated deaths. The project attempted to establish how cocaine deaths are identified and classified, and gauge the level of, and possible reasons, for under-reporting. It is a seminal study in the context of understanding European cocaine deaths, providing fundamental information on such events generally, including causes and mechanisms of death, case demographics, substances involved, and case identification.

This paper focuses on the UK, presenting sources of information used to collect data, and updates information on trends in cocaine-related deaths reported from 1998 to 2012. It discusses the (public) health implications and the gaps in data currently available, to inform future data collection, analysis and research.

\section{Methodology}

This paper draws on data collected as part of an EMCDDA project aimed to describe the trend in numbers of cocaine-related deaths reported to Special Mortality Registers (SMRs) (or GMRs where relevant) (Corkery, 2012). It also uses insights from a complementary study on cocainerelated hospital emergency admissions (Mena et al., 2013) and other published data. 
Two sources of information were used in the UK context. First, all three UK GMRs (the Office for National Statistics (ONS) covering England and Wales; the General Register Office for Scotland (GROS), part of the National Records of Scotland (NRS); the General Register Office for Northern Ireland (GRONI) and the Northern Ireland Statistics \& Research Agency (NISRA) extract deaths related to poisonings by drugs, medicaments, etc. using ICD-10 codes (WHO, 1992, 2010) for adding to special databases set up to monitor DRDs (Christophersen et al., 1998). Text searches of the wording of the medical cause(s) of death are then employed to assign deaths to specific classes of drugs or specific substances as listed in their annual publications on such fatalities (NISRA, 2016; NRS, 2016; ONS, 2016). The case definition used to extract the cocaine-related cases was 'all cases with cocaine mentioned in the cause of death'. Only published statistics were accessed.

The second source used was the UK SMR - the National Programme on Substance Abuse Deaths (NPSAD), based at St George's University of London. The Programme receives information from coroners on a voluntary basis on deaths related to drugs in both addicts and non-addicts in England and Wales, Northern Ireland, the Channel Islands and the Isle of Man. From 2004 to 2011 information was also received from the Scottish Crime and Drug Enforcement Agency, and from 2004 onwards from the General Register Office for Northern Ireland. Since 1997 details of more than 30,000 deaths have been received. The average annual response rate from coroners in England and Wales to NPSAD during the period focussed on in this study, i.e. 2005-9 was between $89 \%$ and 95\% (Ghodse et al., 2010).

To be recorded in the NPSAD database as a drug-related death, at least one of the following criteria must be met: (a) presence of one or more psychoactive substances directly implicated in 
death; (b) history of dependence or abuse of drugs; or (c) presence of controlled drugs at postmortem (Corkery et al., 2014). Internal analysis by the NPSAD team in 2009 indicated that for deaths which occurred in England in 2007 and 2008, 47.7\% met all three criteria, between $49.3 \%$ and $81.5 \%$ met at least two criteria, and between $1.7 \%$ and $11.3 \%$ met only one criterion. These proportions were similar in both years. The basic approach used by the Programme to identify cases involving specific substances is a text search of the cause of death field. However, where a death is described as "multiple drug overdose" (or similar wording) information in the text of the coroner's verdict may be useful for identification of specific substances involved. In addition, reference may be made to the autopsy and/or post mortem toxicology (PM) reports, with special attention being paid to the concentrations of relevant substances and/or their metabolites. These data, together with the coroners' verdicts are used in the allocation of ICD-10 codes. For further information see Corkery et al. (2014). Two categories of cases were extracted from the NPSAD database: first, 'all cases with cocaine mentioned in the cause of death'; and second 'all cases with a positive toxicology for cocaine and/or its metabolites, whatever the cause of death'. The data from the GMRs and NPSAD are not directly comparable but do complement each other; the key differences between the ONS and NPSAD are described in Table 7 of Stephenson and Richardson (2014).

Trend data presented here for the period 1998-2012 7 extend the data presented in the formal EMCDDA project report (Corkery, 2012). For all cases with cocaine mentioned in the cause of death, the total numbers of cases are given for any cocaine combination and whether cocaine was the sole substance. For NPSAD cases retrieved for the period 2005-9 with cocaine mentioned as a cause of death, the gender, age-group, and detailed toxicology findings were 
recorded (i.e. other substances identified). Information on whether the death was overdose (toxicity, intoxication, poisoning, etc.) or not overdose related was also retrieved.

Part I of the Cause of Death on the death certificate or Medical Certificate of Death (for an example of the latter, see Figure 1) should record the causal chain of morbid conditions that led to death, beginning with the condition most proximate to death on line (a) and working backwards to the initiating condition. The lines (a) to (c) in Part I are connected by the phrase 'due to, or as a consequence of'. Part I is designed to facilitate the selection of the underlying cause of death when two or more causes are recorded on the death certificate. Part II seeks other conditions that the certifier believed contributed to death, but were not in the causal chain. There can be an overlap between these categories in terms of the role which cocaine plays, e.g. post mortem (PM) toxicology reveals a lethal level of cocaine which causes death by poisoning. Many cases meet both criteria. However, cocaine may be detected through PM screening or analysis but at 'trace' levels without having contributed to the death, e.g. a car passenger who has consumed cocaine some time before being killed in a fatal road traffic accident.

\section{$\leq$ Figure 1 about here $>$}

In order to establish whether or not any changes in trend were statistically significant or not regression analysis was undertaken using Joinpoint Trend Analysis Software Desktop version 4.2.0.2 (http://surveillance.cancer.gov/joinpoint/). This statistical software permits the analysis of continuous linear trends with change points, i.e. joinpoints, to test whether an apparent change is statistically significant. This approach has been primarily used in cancer research, but has also been employed to look at trends in opioid analgesic and heroin-related deaths (Warner et 
al., 2014), and-methadone-related overdose deaths (Wunsch et al., 2013), and excess mortality in cocaine users (de la Fuente et al., 2013).

\section{Results}

General trends and key findings

Between 1998 and 2012, the period for which data were available for this study, there were 2728 cases of deaths where cocaine was mentioned in the cause of death, registered in the UK by the 3 GMRs. A third $(845 ; 31 \%)$ of these deaths had cocaine only mentioned (Table 21 ). During the same period, the SMR was notified of 2907 relevant cases where cocaine was implicated in the cause of death, of which $510 ; 17.5 \%$ had only cocaine mentioned. There were 4100 cases received by the SMR where cocaine was recorded in the PM toxicology (of which 333; $8.1 \%$ (range $3.0-9.6 \%$ over the period examined) were sole mentions). Over the period $1998-2012,87 \%$ of cases where cocaine was implicated in death were regarded ${ }_{2}$ in terms of underlying cause of death ${ }_{2}$ as poisonings or overdoses according to ICD-10 codes.

Trends

GMR. Figures for the number of registered deaths published (NRS, 2016 for Scotland; NISRA, 2016 for Northern Ireland; ONS, 2016 for England \& Wales) by the three GMRs covering the UK show that any mentions of cocaine in the medical cause of death field on the death certificate totalled 2728 between 1998 and 2012. Such mentions generally rose year on year from 1998 ( $n=69)$ to 2008 ( $n=325)$, but subsequently fell in $2011(n=171)$ before increasing slightly in 2012 
$(n=191)$ - see Table 2. This pattern was echoed by sole mentions. At the UK level, the number of sole mentions rose from 28 in 1998 to 101 in 2008, but fell to 37 by 2011, rising again to 42 in 2012. The ratio of any to sole mentions of cocaine on UK death certificates during the period 1998-2012 averaged 3.23:1 (2728/845) (range 2.20:1 to 4.62:1). The proportion of cases accounted for by sole mentions of cocaine in the cause of death field on UK death certificates averaged $31.0 \%$ (range $21.6-45.5 \%$ ) over the period $1998-2012$.

SMR (NPSAD). In total, 2907 cocaine-related deaths occurring in 1998-2012 were notified to NPSAD by September 2013. The number of cases in which cocaine was implicated in the cause of death (for any type of cocaine-related DRD) rose from 83 in 1998 to 263 in 2002, before falling in 2004 but then peaking at 321 in 2007, decreasing to 156 by 2010, increasing in $2011(n=167)$ and falling again in $2012(n=137)$. In respect of sole mentions, this same pattern obtained: the number rose from 8 in 1998 to 67 in 2008, but fell to 29 by 2012 (geographical coverage was poorer in the first few years of the Programme's operation, which may account for some of this difference). The overall ratio during this period of any to sole mention was 5.70:1 (2907/510) for cause of death (range 10.38:1 to $3.89: 1$ ). The overall proportion of sole cocaine mentions in the cause of death during the period 1998-2012 was $17.5 \%$ (range $9.6-25.7 \%$ ).

A total of 4100 deaths in which PM toxicology reports had any mention of cocaine were notified to NPSAD in the period 1998-2012. Such cases generally rose year on year from $1998(n=83)$ to 2007 and 2008 ( $n=476$ ), but subsequently fell to 242 in 2012. In respect of sole mentions, a similar pattern was present, rising from 8 in 1998 to plateau about 36-37 in 2005-7 but falling to 10 by 2012 . The overall proportion of sole cocaine findings in PM toxicology during the period 1998-2012 was $8.1 \%$ (range 3.0-19.6\%). 
< Table 1 about here >

Depending on the data source, the peak in cocaine-related deaths occurred in either 2007 (SMR) or 2008 (GMR). (The SMR uses the year of occurrence of death, whereas the GMRs report year of death registration.) Overall, a consistent pattern emerges from a comparison of the GMR and SMR trend figures (Figure 1).

\section{< Figure $1 \underline{2}$ about here >}

The results of Joinpoint regression analyses indicate that all six datasets investigated have a single joinpoint (Figure 2). Five out of the six joinpoints occurred in 2007 or 2008, only that for the SMR any cause of death mention is outside this period (2002). All these results are statistically significant $(p<0.05)$. See Table 2 for full details.

\section{< Figure $2 \underline{3}$ about here $>$}

$<$ Table 2 about here >

Key demographic characteristics

Detailed demographic and other information are not published by the UK GMRs in respect of specific substances. The key characteristics for UK SMR cases in 2005-9 where cocaine was mentioned in the cause of death are given in Table 3. The main findings are: the mean age at 
death during the period was 34.3 years (range 15.6 to 81.3 , standard deviation $=9.0$ ). About $89 \%$ were aged less than 45 years old, $56 \%$ were less than 35 years old. The majority were male (84\%); and where ethnicity was known, the majority (88\%) were White. Where information was available, $49 \%$ were employed, $54 \%$ lived with others, $82 \%$ had a history of drug use/addiction, and at least $7 \%$ of the general sample weresample was known to be injectors.

<Table 3 about here>

Underlying cause of death

Out of the 1234 deaths during 2005-9 which involved cocaine in the cause of death, 1082 $(87.7 \%)$ were ascribed an underlying cause as a poisoning or overdose (Table 4). Of the remaining 152 cases, about 14 (1.1\%) could be described as "general medical condition", together with $21(1.7 \%)$ having cardio-vascular and related problems, hanging $36(2.9 \%)$, injuries $10(0.8 \%)$, mental \& behavioural disorders $51(4.1 \%)$, drowning/falls $3(0.2 \%)$, and road traffic accidents $5(0.4 \%)$.

\section{<Table 4 about here>}

\section{Substances implicated}

The mean number of post mortem drugs was 3.4, underlining the role of poly-substance use. In the majority of cases, opiate/opioids (alone or in combination with other substances) are the main feature of cocaine-related DRDs reported to the UK SMR: implicated in $58.2 \%$ of cause of 
death cases in 2005-9 (Tables 5 and 6). Other key substances implicated were alcohol (30\% of cases), drugs for anxiety/insomniahypnotics/sedatives (mainly benzodiazepines, especially diazepam) (18\%), drugs for depressionanti-depressants (9\%), MDMA (5\%), and amphetamines $(5 \%)$. The most frequent combinations of substances (Table 6 ) involve alcohol, medications (excluding opiates/opioids), opiate/opioids, drugs for anxiety/insomniahypnotics/sedatives, and other recreational drugs (amphetamines, ecstasy, etc.). More recently, Novel Psychoactive Substances (NPS) have been seen in cocaine-related deaths; during the period 2005-9 the NPS concerned were piperazines.

$<$ Table 5 about here $>$

$<$ Table 6 about here>

Identification and classification of reported cases

The UK GMRs and SMR distinguish cocaine poisonings from other types of deaths. Poisonings and somatic (i.e. those relating to the body as opposed to mental and behavioural disorders) deaths overlap; it can be difficult to distinguish between them. Apart from cocaine itself, the principal metabolites commonly identified or screened for are: benzoylecgonine, ecgonine methyl ester, cocaethylene and ecgonine. The products of combustion can be a means of distinguishing smoked cocaine/crack from other modes of intake. However, toxicologists are not usually looking for such products. Information on the use of crack immediately prior to death usually comes from police examination of the death scene and/or witness statements. The GMRs and SMR do not distinguish crack from powder cocaine in their publications. 


\section{Discussion}

This paper presents data on what we believe to be the largest number of cocaine-related deaths reported to date, drawing on both GMR and SMR records. Whilst the extent of overlap between the two can be seen in respect of case definitions (Corkery, 2008), the extent to which identification of identical cases for specific drugs occurs can only be established by a dedicated study matching records for individual decedents. Factors which would have to be taken into account include: geographical coverage/reporting compliance; degree of ambiguity over the contribution of index drugs in cause of death described as 'multiple drug overdose', etc.; availability of detailed toxicology; under-identification of non-overdose deaths involving index drugs.

Case identification

In many cases, it is difficult to ascertain if a death was primarily due to cocaine poisoning, or whether it was due to a combination of substances, or the result of a pre-existing health condition precipitated by cocaine use. Compared to the UK, it has been unclear how cocaine deaths are identified in Europe. In particular, deaths occurring shortly after, and induced by, cocaine use, but which are not poisonings in the strict sense (i.e. overdoses), may not have been identified as induced by cocaine, and therefore are not reported (EMCDDA, 2007:19-20). The EMCDDA study found a range of approaches is used to retrieve cocaine-related cases from mortality registries (Corkery, 2012). There are complexities around variation in ICD coding, PM investigation, as well as the identification and reporting of cases in the first instance, e.g. 
distinguishing between clearly direct causality and other factors in particular types of cases (e.g. accidents). Clearly, the lack of consistency in the definition of cocaine-related deaths by UK GMRs and SMRs, as well as databases across Europe makes some inferences from data unreliable, as well as the aggregation of data and between-country comparisons. Two of the three UK GMRs do not have access to post mortem toxicology, and the third only has some indication from pathologists as to possible drugs implicated (NRS, 2015). A wider range of factors is used by NPSAD, facilitating greater flexibility in approach: toxicology, autopsy, evidential information and cause of death.

Representativeness

Levels of under-identification and reporting cannot be gauged without undertaking further investigations to establish in detail the full range of reasons for under-reporting and their extent. However, NPSAD has been receiving access to all Northern Ireland drug poisoning deaths data. Some information is available on comparisons between Scottish Crime \& Drug Enforcement Agency (SCDEA) and the Scottish GMR (now NRS) data for 2006 deaths. A core number of 321 deaths were counted by both the GMR and SCDEA; 100 deaths were counted by the GMR but not by SCDEA; and 53 cases were counted by SCDEA but not by the GMR (see Annex B of NRS, 2016). An audit of coronial files found that $3-4 \%$ of relevant cases had not been reported to NPSAD (Ghodse et al., 2010).

One cannot simply add together the figures from GMRs and SMRs to establish the absolute number of cocaine-related deaths BRDs. The extent of overlap between cases recorded by the UK GMRs and NPSAD is not known in respect of drug-induced deaths generally nor for 
cocaine-related deaths DRDs specifically. However, it is known that there are benefits in using these two different but complementary sources. They can each be used to cross-check or validate the findings of the other (i.e. triangulation). They are not alternatives since they have different functions.

It would be beneficial to both the GMRs and NPSAD to be able to exchange information on named individuals on a regular and routine basis so that all relevant cases are identified, and thus both databases made more complete and accurate. The extent of overlap between them needs to be established. However, legislation restricts the way in which the GMR for England \& Wales can share information with non-Governmental bodies; this limits the extent to which information can be exchanged between the two bodies. For ad hoc studies it is necessary for the SMR to register that specific project as a medical study. Consideration could be given to see if such an arrangement could be extended to the surveillance work as a whole, or to an alternative mode of working. For this reason, we did not compute rates of cocaine-related mortality which could be misleading as the reporting systems differ and make it difficult to compute sufficiently robust rates at the population level. This allows trends over time to be observed, but does not risk misleading readers with estimates whose precision is open to question.

For the most part, it is difficult to compare the data provided by one country with that from another for several reasons: (a) different types of data sources from registries with different roles, purposes and nature; (b) underlying differences in the data-items collected; (c) different definitions of DRDs, even where based on ICD-10 codes there are varying approaches; (d) different criteria used to define cocaine-related DRDs; (e) varying lengths of time for which data 
are available; and (f) delays in publishing data. It is possible to look at trends over time within a country/region, but even then consistency of data may vary over time in terms of geographical coverage (e.g. the UK SMR), quality of data reported, and level of detail recorded. These are issues common to previous EMCDDA data-collation exercises (e.g. Wirl, 2010).

Trends

During the 15-year period examined here (1998-2012), a considerable number of deaths was identified in the UK by both the GMRs (2728 death registrations) where cocaine was mentioned in the cause of death, and by the SMR (a minimum of 2907 deaths occurring) where cocaine was involved in the death. Such deaths accounted for about $5.23 \%$ of poisoning as an underlying cause in GMRs (using a broad definition of drug) and $10.43 \%$ of SMR deaths involving psychoactive substances in respect of UK DRDs. This constitutes a considerable health burden and a significant number of premature deaths that are largely preventable.

In Europe during the 2000s there was generally an increasing upward trend in cocaine-related deaths, followed by a decline in most countries (EMCDDA, 2011). However, the latest reports from NPSAD indicate a stabilisation in terms of cocaine deaths in 2011 (Corkery et al., 2014), but an-increases between 2012 and $2013 \underline{4}$ in England (Claridge \& Goodair, 2015,2017). The UK GMR death registrations in 2011-15 indicate a rise in such deaths (NISRA, 2016; NRS, 2016; ONS, 2016). The decrease after 2008 is consistent with morbidity data in the UK (Mena et al., 2013; PHE, 2014). Although new presentations for treatment in England showed a continuous decline for primary crack use from $2007 / 8$ to $2013 / 4$, such notifications for cocaine 
show a continuous rise from $2011 / 2$ to $2013 / 4$ (PHE, 2014). These patterns are replicated at a UK level (Burton et al., 2014). Close monitoring is still required.

The patterns in UK cocaine-related DRDs need to be set in a wider context. Cocaine-related mortality could also be related to a wider set of indicators, as done a number of years ago for the UK (Schifano and Corkery, 2006, 2008). Part of the recent decline apparent in some countries (EMCDDA, 2013a), may be related to a decline in cocaine purity and/or a shift to using alternative stimulants, including 'legal highs' (Corkery, 2012; EMCDDA, 2013b). The UK street price of cocaine powder seized by law enforcement agencies fell from $£ 60$ per gram in 2000 to $£ 40$ in 2008 and remaining at that level through to 2013 (Burton et al., 2014). However, the lower prices are probably due to the poorer quality of the cocaine. The mean purity of powder cocaine seized by the police in England \& Wales fell from $33 \%$ in 2007 to $20 \%$ in 2009 before rising again to $38 \%$ in 2013 ; the purity of 'crack' cocaine is reported to have fallen during the same period from $52 \%$ to $27 \%$ in 2009 before rising to $36 \%$ in 2013 (Burton et al., 2014). 'Last year 'use of powder cocaine amongst 16-59 year-olds in England \& Wales fell from $3.0 \%$ in $2008 / 9$ to $1.9 \%$ in $2012 / 13$ before rising to $2.3 \%$ in $2014 / 5$ (Lader, 2015 ). The number of cocaine seizures in England \& Wales peaked in 2008/9 and that for crack in 2007/8 since when both showed declining trends to 2012/3 with a stabilisation in 2013/4 (Dhani, 2014). The quantities seized fell for cocaine from 2003 to 2009/10, recovered slightly in 2011/2, fell back in $2012 / 3$ but recovered in $2013 / 14$ to a level similar to that in $2007 / 8$; for crack it fell back in 2008/9 before rising in 2009/10, fell in 2011/2, rising again in 2012/3 and 2013/4.

There is now emerging evidence of a large problem of cocaine-related morbidity leading to hospitalisation and emergency visits (Mena et al., 2013). Chiefly involving males and young 
patients (15-29 years old), they appear to follow patterns similar to those in cocaine DRDs in recent years. It has even been proposed that the fall in ecstasy and cocaine-related deaths in the United Kingdom since 2008 may have been as a result of users switching to 'legal highs' with the suggestion that this may have had an unintended harm reduction effect (Bird, 2010).

Demographic characteristics

The majority of cocaine-related deaths in 2005-9 reported to NPSAD occurred in the 20-24 to 45-49 years age-groups (minimum 15, maximum 81). Mean age at death for these cocaine cases is typically in the late 20 s or early 30 s, much younger than the mean commonly reported by the GMR using the EMCDDA Standard (41 years according to 2012 reporting) (i.e. all overdose deaths, accounted for mainly by opioid-related cases). Males accounted for $84 \%$ of cases, broadly in line with the general findings for UK deaths reported to the EMCDDA; this proportion is higher than the approximately 75\% usually seen for 'typical' SMR cases in 2012. Half $(36 \%)$ were unemployed compared to $52 \%$ of NPSAD deaths in 2012 . Higher rates of last year powder cocaine use are higher in the groups with the lowest household income category of $<£ 10 k$ (typically those receiving social benefits/unemployment benefits) or at the other extreme those with a household income $>=£ 50 \mathrm{k}$ (Home Office, 2013). A higher proportion of cases in the present study (54\%) were living with someone else compared to 2012 NPSAD cases (44\%). Cocaine fatalities ( $82 \%$ ) had a considerably higher occurrence of having a history of drug use than NPSAD cases in 2012 (67\%). A wider range of ethnicities died from cocaine use during this period ( $88 \%$ White) compared to those recorded for NPSAD cases in general in $2012(97 \%$ White) (Corkery et al., 2014). 
Characteristics of deaths

The vast majority ( $88 \%)$ of SMR deaths where cocaine was involved in the death were regarded as poisonings or overdoses involving this substance and/or its metabolites; similar to that found for NPSAD cases in 2012 (Corkery et al., 2014). Some 13\% of cases had a reported preexisting cardiovascular/cardiopulmonary condition, with $22 \%$ developing primarily cardiac and pulmonary medical conditions, reflecting the dangers already known about cocaine (see Table 7). Regular cocaine use can increase systolic blood pressure, aortic stiffness and left ventricular mass; these are well-recognised as risk factors for premature cardio-vascular events (Kozor et al., 2014).

More individuals experimenting with the drug is a cause for serious concern, especially those with underlying coronary artery disease as it increases double product (heart rate $\mathrm{x}$ systolic blood pressure) and myocardial oxygen demand (Howard et al., 1985). Of note in this context is coronary atherosclerosis - particularly of the left anterior descending coronary artery (Darke et al., 2006); this is because a higher proportion of the minority of subjects at risk of acute cocaine medical sequelae and fatalities (genetic causes, such as fully or partially expressed congenital long QT syndrome, may play a role; Karch, 2005) will be more likely to be self-administering the compound (Webb et al., 2003). Furthermore, greater availability of cocaine formulations means that some consumers may find it easier to enter a chronic consumption pattern. According to Karch (2005), most deaths occur after prolonged drug use, which can induce a series of changes at the molecular, cellular, and tissue levels. Potentially lethal myocardial alterations include hypertrophy, fibrosis, and microangiopathy and all of these changes favour sudden death, possibly through hypertension, arrhythmias, and cardiac infarction (Knuepfer, 2003; 
Vasica and Tennant, 2002). Darke et al. (2005) found cardiac pathology in $57 \%$ of 146 cocainerelated fatalities, most commonly coronary artery atherosclerosis (39\%) and cardiac hypertrophy (14\%); cerebrovascular pathology was noted in $22 \%$ of cases.

\section{<Table 7 about here>}

Both the GMR and SMR UK data show that polydrug abuse ingestion was involved in most cocaine-related fatalities. This closely mirrors an earlier study looking at amphetamine/ methamphetamine and ecstasy deaths reported to NPSAD, where ecstasy fatal ingestion seemed to be most typically identified together with cocaine (Schifano et al., 2010), and both drugs are frequently associated with the recreational scene (Winstock and Schifano, 2009). Cooccurrence of two stimulants (i.e. MDMA together with cocaine) might increase, in a synergic way, both the dopaminergic and serotonergic stimulation, so that the 'serotonin syndrome' is more likely to occur (Schifano, 2004). Cocaine/amphetamine users have an increased risk of death (Arendt et al., 2011).

Contributory clinical factors described here at post mortem in cocaine fatalities were overall consistent with the existing literature, often anecdotal in nature, and reflect a number of issues, including: the sympathomimetic action of cocaine (Liaudet et al., 2014); the-possible idiosyncratic toxic reactions to this drug (Bromley and Hayward, 1988; Chakko and Myerburg, 1995); and the-risk-taking behaviour byøf cocaine misusers (Pavarin et al., 2011). These findings are similar to those found in respect of ecstasy and amphetamine/methamphetamine fatalities (Schifano et al., 2010). 
CNS suppressants such as opiates (especially heroin/morphine), drugs for anxiety/insomniahypnotics/sedatives (principally benzodiazepines) and alcohol contribute significantly to UK cocaine-related deaths - whether only with cocaine or with cocaine and other drugs. Other medications and 'recreational' drugs contribute less to cocaine deaths - but it is important to note the contribution played by other stimulants, i.e. ecstasy and amphetamines. In $22.4 \%$ of all NPSAD deaths in which cocaine was implicated in $2005-9$, it was the only drug implicated.

For NPSAD overall in 1998-2012, there were 11.4 times more PM cases with cocaine and other substances than cases with only cocaine mentioned; the ratio for such 'mentions' in the cause of death field was 4.7. The overall proportion of sole cocaine 'mentions' in the cause of death during the period $1998-2012$ was $17.5 \%$ (range $9.6-25.7 \%$ ). This finding was echoed by the PM toxicology findings, where the overall proportion of sole cocaine findings in PM toxicology during the period $1998-2012$ was $8.1 \%$ (range $3.0-19.6 \%$ ). These results reflect a trend towards polysubstance abuse; an average of 3.37 substances was found in PM toxicology in 2005-9.

The number of cases where cocaine was found in PM toxicology was $44.5 \%(n=4200)$ higher than the number where it was implicated in the cause of death $(n=2907)$. The ratio for 19982012 was $1.44: 1$.

The clearest feature is that opiates/opioids are involved in most cases (58\%), often without other substances. This dominant presence of opiates/opioids in cocaine-related DRDs (mostly defined here as poisoning/overdoses) mirrors wider patterns evident in European and UK DRDs (Burton et al., 2014; EMCDDA, 2015). The large proportion of cocaine-related deaths in the 
present study involving heroin, methadone or other opioids also echoes that in respect of our earlier study of amphetamine/methamphetamine users (Schifano et al., 2010). These are drugs with high levels of toxicity in overdose and typically associated with the 'hard core' addiction scene (Ghodse et al., 2008). This suggests that many cocaine users are problematic and polysubstance users; both factors increasing the risk of overdose/poisoning and of death.

Alcohol (either alone or together with other drugs) was identified in combination with cocaine in about $21 \%$ of NPSAD cases in 2005-9. Cocaine and ethanol are commonly consumed the same time (Schifano, 2001). Cocaine is transesterified by liver esterases to cocaethylene, which has cocaine-like pharmacologic properties, in the presence of ethanol (Dean et al., 1991). Both ethanol and cocaethylene reduce mean cocaine clearance by $47 \%$ and $26 \%$, respectively (Parker et al., 1996). The effect of cocaine is therefore prolonged and the 'comedown' following cocaine is diminished (Schifano and Corkery, 2008).

Non-poisoning/overdose cases

Poisonings and somatic deaths overlap so it can be difficult to distinguish between them. For most GMRs, including the UK, the mode of use or route of administration of cocaine is not known/recorded. The UK SMR (NPSAD) does record such information when available, but is dependent on the quality of data submitted. These factors may lead to under-identification of somatic cases associated with cocaine use, as the link would only be apparent from evidential information or intelligence. 
In the UK SMR most cocaine-related cases (87\%) were ascribed to underlying cause in 2005-9. 'General medical condition' appears to play a large contribution to non-overdose cases, about one-third in the UK. This category encompasses a whole range of underlying causes of death which might merit closer examination in the future using a finer-grained approach. Some nonoverdose cases due to cocaine are recorded. These are even more likely than poisoning to be underestimated, e.g. excited delirium, road traffic accidents (RTAs). Deaths involving accidental injury and RTAs also feature as do suicides (often by hanging) in most countries, especially in the UK.

Mental and behavioural disorders play a role in UK deaths. For example, in 2011-2 the mortality rate for service users in England recorded in the Mental Health Minimum Dataset was 4008 deaths per 100,000 compared to 1122 deaths per 100,000 in the general population - 3.6 times higher (HSCIC, 2013). Premature mortality attributable to illicit drug dependence was calculated as Years of Life Lost (YLL) based on cause of death estimates by the Global Burden of Disease (GBD) team for the year 2010 (Degenhardt et al., 2013). An estimate of 25,000 YLL due to cocaine dependence was indicated, contributing $5.5 \%$ of the drug dependence considered. This equates to 4290 deaths worldwide each year (i.e. $5.5 \%$ of 78,000 deaths p.a. due to illicit drug disorders). In the present study, $4 \%$ of cocaine poisoning deaths in $2005-9$ reported to the UK SMR were due to intoxication, dependence, etc. Suicide by regular users of cocaine was found by the GBD team to be a significant contributor to the illicit drug burden. In addition, cocaine dependence accounted for 6.9 million cases of mental and substance use disorders worldwide in 2010 (Whiteford et al., 2013). In Western Europe there were an estimated 640,700 cases with a further 62,000 in Central Europe (Degenhardt et al., 2014). 
At-risk groups

The data from the UK SMR (see Tables 5, 6 and 7) suggest the possibility of five categories of cocaine users at greater risk of dying:

(a) those using cocaine in the context of opioid use, especially heroin and methadone (Pavarin, 2013; de la Fuente et al., 2014);

(b) those using cocaine with alcohol, as in the 'champagne' (Shapiro, 2002; Santos et al., 2012) style or mode (Roe and Man, 2006);

(c) those using cocaine in the context of psychiatric problems or experiencing psychiatric problems consequent to cocaine misuse/abuse (Arendt et al., 2011; Addy et al., 2012) (instances of psychiatric medications, i.e. drugs for depressionantidepressants and/or drugs for psychosisantipsychotics implicated in death);

(d) those consuming cocaine in the context of recreational drug use, including other stimulants (amphetamine, ecstasy), GHB/GBL, ketamine and Novel Psychoactive Substances, e.g. in night clubs, discos (Roe and Man, 2006; Home Office, 2012; Corkery et al., 2015); and

(e) those with cardiovascular/remaining medical conditions (Cregler, 1989; Gray, 1993; Pavarin et al., 2011). 
Some of these groups are redolent of those identified/described in the British Crime Survey (Roe and Man, 2006). A limitation of the profile of users is that it is based on deaths only up to 2009. If the period was extended not only would there be more cases on which to draw conclusions but also one would be able to see if any of the characteristics changed over time, especially in response to the emergence of NPS. In this study period (2005-9) the only NPS class emerging was piperazines. Since then, other stimulants such as synthetic cathinones and cannabinoids have appeared (Schifano et al., 2015).

Toxicological analysis

There may be some types of death where toxicological analysis may not be undertaken or the role of psychoactive substances is underplayed because of the main cause of death e.g. assaults, suicides (particularly using violent means such as hanging), or accidents (RTAs, drowning, accidental injury). Such cases may therefore not be recorded as drug-related let alone as cocaine-related. Thus, the data provided here are likely to underestimate the presence of and/or involvement of cocaine in these kinds of unnatural death.

EMCDDA DRD experts consider that guidance is needed on interpretation of post mortem toxicology levels to define overdoses/poisonings (Corkery, 2012). There are wide variations in levels considered be toxic/fatal/lethal, especially when considering post mortem redistribution. These levels can be affected by poly-substance use and metabolism. It is important to know fatal levels for sole cocaine deaths. Bertol et al. (2008) suggest that it is not generally possible to correlate specific blood/tissue concentrations with toxicity. However, some guidance on post mortem toxicology levels and help in the operationalisation of these aspects is available (Lahti 
et al., 2009; Stephens et al., 2004). Equally important is the need to identify the effect of polysubstance use on what should be regarded as fatal levels. New challenges in this area are posed in monitoring and understanding such deaths because of the growing trend towards using multiple stimulants.

\section{Cutting agents}

Consideration needs to be taken of the potential contribution to cocaine-related deaths played by common cutting-agents found in powder cocaine - and to a lesser extent in 'crack'. Cutting agents include both pharmacologically inactive substances with a similar appearance i.e. diluents (e.g. sugars such as mannitol) and adulterants which are pharmacologically active components that may alter a drug's properties. It has been suggested that the addition of adulterants to cocaine is to meet increased demand for the drug, they are cheaper alternatives to cocaine, and they can be used to increase profits by diluting the final product (Brunt et al., 2009). Cocaine derivatives such as benzocaine, lidocaine/lignocaine, procaine, as well as caffeine, are common examples.

Over the past two decades the following adulterants, which are 'per se' associated with levels of toxicity (Pawlik et al, , 2015), have been found in cocaine seized by law enforcement agencies and/or PM toxicological assays in the UK and Western Europe: atropine, benzocaine, caffeine, diltiazem, ephedrine, hydroxyzine, levamisole, lidocaine/lignocaine, paracetamol, phenacetin, procaine (King, 1997; Brunt et al., 2009; Evrard et al., 2010; Schneider and Meys, 2011). There appear to have been increases in caffeine, diltiazem, hydroxyzine and levamisole since 2007 but a decrease in lidocaine over the years. The diversity of adulterants in cocaine has increased 
considerably (Brunt et al., 2009), and up to 14 may be found in one sample (Schneider and Meys, 2011). The commonest adulterants in UK seizures in during 2014 were (LGC, 2015): powder cocaine - benzocaine, caffeine, creatine, diltiazem, levamisole, lignocaine, paracetamol and phenacetin; crack - benzocaine, caffeine, levamisole and phenacetin.

Generally speaking, adulterated cocaine is more likely to give rise to reported adverse effects than purer forms (Brunt et al., 2009). However, Brunt et al. (2009) suggest that such reports are more likely in relation to diltiazem, hydroxyzine and phenacetin, but not caffeine, levamisole, lidocaine/lignocaine and procaine. The possibility of interactions between adulterants and cocaine is not well researched. Additional concerns are that: often durations of exposure are unknown (Brunt et al., 2009; Evrard et al., 2010); users are unable to detect specific adulterants (Evrard et al., 2010); the variable purity level and the wide range of adulterants can lead to unpredictable clinical effects (Evrard et al., 2010); and many of these adulterants are prescribed for oral ingestion in therapeutic treatment but pharmacokinetic properties such as absorption, bio-availability, distribution, metabolism and kinetics may be affected by other administration routes (Brunt et al., 2009; Pawlik et al., 2015). If cocaine is insufflated or smoked the adulterants will also be incorporated into the lung initially (Pawlik and Mahler, 2013), and may result in lung damage or disease (Hollinger, 1993; Kehrer and Kacew, 1985). Lidocaine, for example, may cause pulmonary parenchymal damage, and levamisole's metabolite - aminorex - causes pulmonary hypertension (Hollinger, 1993).

Limitations

http://mc.manuscriptcentral.com/jop 
Detailed demographic and other information are not published by the UK GMRs in respect of specific substances. Only the Scottish GMR has access to toxicological information, and even that is very limited. However, in recent years the Scottish DRD database has linked GMR data with information regarding toxicology and pathology and publishes some more detailed analysis (Barnsdale et al., 2016). A similar approach could be used to advantage in other parts of the UK.

Although the UK SMR results suggest that most cocaine-related deaths are also opiate/opioidrelated and/or polydrug poisoning cases, it is likely that some cocaine-related fatalities will be missed by the DRD Key Indicator data based on UK GMR data. This is because UK GMRs do not typically have access to toxicological information and up to $12 \%$ of all drug poisonings fatalities in the UK recorded by the GMRs are recorded as multiple/substances intoxications/overdoses without specific substances being recorded on the death certificate (ONS, 2014).

Limited data were available when the original study was conducted. Looking at SMR data over a longer period would provide a larger dataset for analysis and facilitate an examination of trends in characteristics of both individuals experiencing cocaine-related fatalities and also of the mechanisms/causes of death an any change in contributing factors, especially with regard to the consumption of other psychoactive substances (including alcohol) and the adulterants used as cutting agents. Also an examination of mortality trends splitting cases into ones involving opiates/opioids vs. other substances may reveal other issues of interest.

\section{Conclusions}


GMR information provides some indications of long-term trends and possible numbers of cases of deaths related to cocaine, as does UK SMR data. The latter is beneficial in providing a more in-depth understanding of the characteristics of decedents and the nature of their deaths. As with other projects looking at DRDs, the EMCDDA project faced problems arising from the different nature, purposes, roles and type of data recorded by individual registries, especially SMRs. The level of detail, use or not of ICD codes and other information to identify relevant cases, as well as varying selection criteria are impacted by those differences. In turn, this affected the quality and type of data submitted. However, this project gives pointers for where further refinement could be targeted. Guidance is needed on the PM toxicology levels to define overdoses/poisonings. There are wide variations in levels considered toxic/fatal/lethal. These levels can be affected by poly-substance use and metabolism in terms of blood levels. It is important to know levels for sole cocaine and poly-substance deaths. The provision of such guidance across the EU and UK may help improve case-identification both prospectively and in any future retrospective data analyses.

This analysis of fatalities that did not arise through overdose suggests that it would be valuable to examine more closely those cases ascribed to 'general medical conditions', 'cardiovascular and other issues', etc. The scientific medical literature is increasingly featuring small-scale casestudy or anecdotal reports of conditions associated with the acute and chronic use of cocaine. Mena et al. (2013) found a considerable increase in the numbers of cocaine-related hospital episodes and emergency admissions since the end of the 1990s in the countries that reported the highest number of episodes, numbers peaking around 2007/8 in Spain and the UK. This underlines the importance of seeking a more accurate picture of the numerical extent of such 
conditions and a fuller understanding of what conditions and diseases are caused, and how, by cocaine use. Other areas that could also be examined in the future include: the role of cocaine in deaths involving accidental injuries, road traffic accidents, and suicides - especially by hanging. There is anecdotal material, including from the UK, to suggest that stimulants (such as cocaine, MDMA, amphetamine, and more recently methcathinones) are often consumed by the decedents in such cases; published literature on these aspects is very limited, e.g. Rajs \& Fugelstad (1999), Oyefeso et al. (2006),

Further research is needed on the clinical implications of cocaine misuse in the context of polydrug intoxication - especially with regard to possible changes over time in the coingestion/administration of opioids on the one hand and stimulants on the other, with deaths where cocaine was directly related to death and other cases where it was just found at post mortem being compared, and should also specifically address the issue of possible individual psychobiological/genetic vulnerability to deaths caused by cocaine (Schifano and Corkery, 2008). The role of adulterants in cocaine in contributing to death also warrants further investigation.

In conclusion, cocaine-related DRDs have become an important feature of drug-related mortality in the UK and Europe generally - perhaps accounting for more than 1000 deaths each year. These are likely to continue to be so in the future, due to the large number of chronic and problematic users. There are at least 42,000 cocaine/crack users seeking treatment in the UK in recent years (personal communications from Public Health England on 16 January and 25 February 2015 to lead author; ISD Scotland 2014; DHSSPSNI, 2014; Welsh Government \& NHS Wales, 2014). Furthermore, we have noted in the UK increasing quantities of cocaine 
powder and crack being seized by law enforcement agencies, rising purity levels for street cocaine and crack, and increasing presentations for treatment by primary cocaine users. All of these would suggest the potential for continuing or rising numbers of deaths due to cocaine use. Indeed, there are indications that cocaine-related deaths across the UK are on the increase again (NISRA, 2016; NRS, 2016; ONS, 2016). It is necessary to understand the nature and extent of this phenomenon. Some core commonalities have been observed in respect of the UK, but more information is needed, especially since they accounted for $5 \%$ of all UK poisoning deaths registered in the period 1998-2012, an average of 174 deaths each year. The data and information presented in this paper and the EMCDDA project (Corkery, 2012) provides the first insights into the nature and possible extent of the phenomenon of cocaine-related DRDs in the UK and Europe.

\section{Acknowledgments}

The authors would like to thank the anonymous reviewers who provided very helpful suggestions for revisions to the draft version of this paper and ideas for further analyses, the latter being especially fruitful.

\section{Roles played by individuals}

JC - lead author; FS contributed to writing the paper; CG and HC contributed to writing the paper and providing data from the National Programme on Substance Abuse Deaths (NPSAD), St George's University of London. 


\section{Funding}

Analysis of the data sources, numbers and characteristics of cocaine-related DRD cases reported in Special Mortality Registries, or eventually in General Mortality Registries (GMR) when necessary (Contract code: CC.11.EPI.14). Lisbon: European Monitoring Centre for Drugs and Drug Addiction. Data used in this paper were collected during routine NPSAD surveillance activities. Financial support was provided during 2004-10 by the Department of Health (England) and 2010-11 by the National Treatment Agency (for England). These agencies had no involvement in preparation of the article, study design, collection, analysis and interpretation of data, writing of the article, or the decision to submit for publication.

\section{Conflicts of interest}

JC acted as the Drug-related Deaths expert for the United Kingdom's Focal Point on Drugs (UKFP) from 2000 to 2015, and continues to provide advice. CG and HC run the National Programme on Substance Abuse Deaths (NPSAD), and JC and FS were formerly part of NPSAD. The views expressed here reflect only the authors' views and not necessarily those of the UKFP or the EMCDDA.

\section{Declaration}

This work has not been previously published and has not been submitted for publication elsewhere. Publication is approved by all authors and the responsible authorities where the 
research was undertaken. If accepted, the paper will not be published elsewhere in the same form, in English or in any other language, without the written consent of the copyright holder.

\section{Ethical approval}

The Central Office for Research Ethics Committees (COREC), National Patient Safety Agency confirmed in writing (February 2006) that the NPSAD Programme does not require NHS REC review as the subjects of the research are deceased. The GMR data are in the public domain. 
References

Addy PH, Radhakrishnan R, Cortes JA and D'Souza DC (2012) Comorbid alcohol, cannabis and cocaine use disorders in schizophrenia: epidemiology, consequences, mechanisms, and treatment. Focus. 10(2):140-153. DOI: 10.1176/appi.focus.10.2.140

Arendt M, Munk-Jørgensen P, Sher L and Jensen SOW (2011) Mortality among individuals with cannabis, cocaine, amphetamine, MDMA, and opioid disorders: a nationwide follow-up study of Danish substance users in treatment. Drug and Alcohol Dependence. 114(2-3):134-9. DOI: 10.1016/j.drugalcdep.2010.09.013. PubMed PMID: 20971585.

Barnsdale L, Gordon R, Graham L, Walker D, Elliott V, and Graham B (2016) The National Drug-Related Deaths Database (Scotland) Report: Analysis of Deaths occurring in 2014. 22 March. Information Services Division, Scottish Government, Edinburgh. . Available at: http://www.isdscotland.org/Health-Topics/Drugs-and-Alcohol-Misuse/Publications/2016-0322/2016-03-22-NDRDD-Report.pdf (accessed 31 October 2016)

Barrio G, Molist G, de la Fuente L, Fernández F, Guitart A, Bravo MJ, Brugal MT and Itinere Working Group (2013) Mortality in a cohort of young primary cocaine users: controlling the effect of the riskiest drug-use behaviors. Addictive Behaviour. 38(3):1601-4. DOI:

10.1016/j.addbeh.2012.10.007. PMID: 23254204

http://mc.manuschiptcentral.com/jop 
Bertol E, Trignano C, Di Milia MG, Di Padua M and Mari F (2008) Cocaine-related deaths: an enigma still under investigation, Forensic Science International. 176(2-3):121-123. PubMed PMID: 17764862.

Bird S (2010) Banned drug may have saved lives, not cost them. Available at: http://www.straightstatistics.org/article/banned-drug-may-have-saved-lives-not-cost-them (accessed 16 September 2015).

Bromley L and Hayward A (1988) Cocaine absorption from the nasal mucosa. Anaethesia. 43(5):356-358. DOI: 10.1111/j.1365-2044.1988.tb09011.x. PubMed PMID: 3400843.

Brunt TM, Rigter S, Hoek J, Vogels N, Dijk P and Niesink RJM (2009) An analysis of cocaine powder in the Netherlands: content and health hazards due to adulterants. Addiction. 104(5):798:805. DOI: 10.1111/j.1360-0443.2009.02532.x. PubMed PMID: 19413792.

Burton R, Thomson F, Visintin C and Wright C (eds) (2014) United Kingdom drug situation: annual report to the European Monitoring Centre for Drugs and Drug Addiction (EMCDDA) 2014. 19 December. London: Public Health England. Available at: http://www.nta.nhs.uk/uploads/uk-focal-point-report-2014.pdf (accessed 16 September 2015). Chakko S and Myerburg RJ (1995) Cardiac complications of cocaine abuse. Clinical Cardiology. 18(2):67-72. DOI: 10.1002/clc.4960180206. PubMed PMID: 7720292. 
Christophersen O, Rooney C and Kelly S (1998) Drug-related deaths: methods and trends, Population Trends. 93: 29-37. Available at:

http://www.ons.gov.uk/ons/rel/population-trends-rd/population-trends/no--97--autumn1999/population-trends.pdf (accessed 16 September 2015).

Claridge H, Goodair C (2015) Drug-related deaths in England, Northern Ireland, the Channel Islands and the Isle of Man, January-December 2013. London: St George's University of London. Available at: $\quad$ http://www.sgul.ac.uk/images/NPSAD - Drugrelated deaths in England Northern Ireland the Channel Islands and the Isle of Man J anuary-December 2013.pdf (accessed 4 March 2017).

Claridge H, Goodair C (2017) National Programme on Substance Abuse Deaths (NPSAD): Drug-Related Deaths in 2014. 2 February 2017. London: St George's University of London. Available at: http://www.sgul.ac.uk/images/Research/Pop Health/DeathsEnglandNI2014NPSADTables.xlsx (accessed 4 March 2017).

\section{Corkery J (2008) UK drug-related mortality - issues in definition and classification, Drugs and} Alcohol Today, 8(2): 17-25.

Corkery JM (2012) Analysis of the data sources, numbers and characteristics of cocaine-related DRD cases reported in Special Mortality Registries, or eventually in General Mortality Registries (GMR) when necessary. A Report for the European Monitoring Centre for Drugs and Drug Addiction. 15 November. Lisbon: EMCDDA. Available at: 
http://www.emcdda.europa.eu/attachements.cfm/att 191876 EN Cocaine deaths DRD final1.pdf

Appendices:

http://www.emcdda.europa.eu/attachements.cfm/att 191877 EN Appendix1 Responses\%20to \%20cocaineDRDs $\% 20$ minisurvey.pdf

http://www.emcdda.europa.eu/attachements.cfm/att 191878 EN Appendix2 DraftProtocol for Cocaine DRDs mainStudy.pdf

http://www.emcdda.europa.eu/attachements.cfm/att 191879 EN Appendix3 Templates\%20for \%20cocaine $\% 20$ DRD $\% 20$ main $\% 20$ study.pdf

http://www.emcdda.europa.eu/attachements.cfm/att 191880 EN Appendix4 Cocaine Related DRDs Cases by\%20Country.xls (accessed 16 September 2015).

Corkery J, Claridge H, Loi B, Goodair C and Schifano F (2014) Drug-related deaths in the UK: Annual Report 2013. Drug-related deaths reported by Coroners in England, Wales, Northern Ireland, Guernsey, Jersey and the Isle of Man; Police forces in Scotland; \& the Northern Ireland Statistics and Research Agency - Annual Report January-December 2012. 12 February. London: International Centre for Drug Policy, St George's University of London. Available at: http://www.sgul.ac.uk/images/docs/idcp\%20pdfs/National\%20programme\%20on\%20substance \%20abuse\%20deaths/National Programme on Substance Abuse Deaths-

Annual Report 2013 on Drug-related Deaths in the UK January-December 2012 PDF.pdf (accessed 16 September 2015).

Corkery JM, Loi B, Claridge H, Goodair C, Corazza O, Elliott S, Schifano F (2015) Gamma hydroxybutyrate (GHB), gamma butyrolactone (GBL) and 1,4 butanediol (1,4-BD; BDO): a 


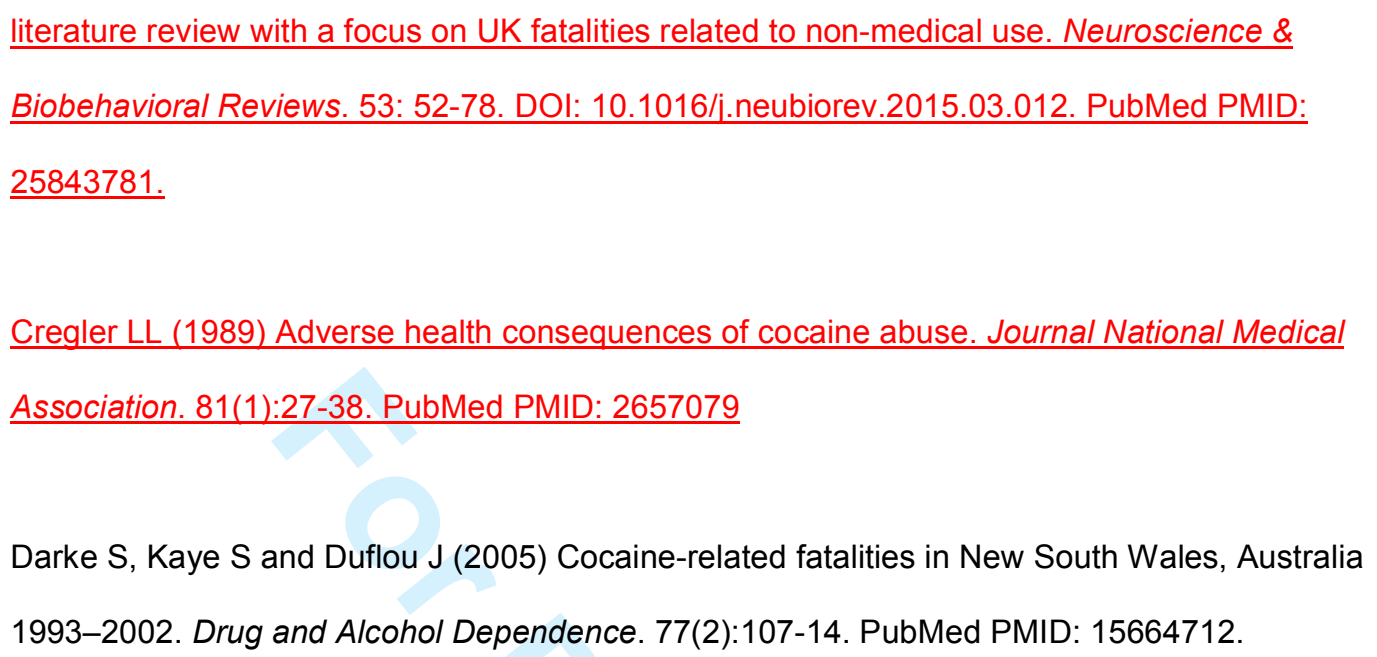

Darke S, Kaye S and Duflou J (2005) Cocaine-related fatalities in New South Wales, Australia 1993-2002. Drug and Alcohol Dependence. 77(2):107-14. PubMed PMID: 15664712.

Darke S, Kaye S and Duflou J (2006) Comparative cardiac pathology among deaths due to cocaine toxicity, opioid toxicity and non-drug-related causes. Addiction. 101(12):1771-7. PubMed PMID: 17156176.

Dean RA, Christian CD, Sample RH and Bosron W F (1991) Human liver cocaine esterases: ethanol-mediated formation of ethylcocaine. FASEB Journal. 5(12): 2735-2739. PubMed PMID: 1916095.

Degenhardt L, Baxter AJ, Lee YY, Hall W, Sara GE, Johns N, Flaxman A, Whiteford HA and Vos T (2014) The global epidemiology and burden of psychostimulant dependence: findings from the Global Burden of Disease Study 2010. Drug and Alcohol Dependence. 137:36-47. DOI: 10.1016/j.drugalcdep.2013.12.025. PubMed PMID: 24559607. 
Degenhardt L, Singleton J, Calabria B, McLaren J, Kerr T, Mehta S, Kirk G and Hall WD (2011) Mortality among cocaine users: a systematic review of cohort studies. Drug and Alcohol Dependence. 113(2-3):88-95. DOI: 10.1016/j.drugalcdep.2010.07.026. PubMed PMID: 20828942.

Degenhardt L, Whiteford HA, Ferrari AJ, Baxter AJ, Charlson FJ, Hall WD, Freedman G, Burstein R, Johns N, Engell RE, Flaxman A, Murray CJ and Vos T (2013) Global burden of disease attributable to illicit drug use and dependence: findings from the Global Burden of Disease Study 2010. Lancet. 382(9904):1564-74. DOI: 10.1016/S0140-6736(13)61530-5. PubMed PMID: 23993281.

de la Fuente L, Molist, G, Espelt A, Barrio G, Guitart A, Bravo MJ, Brugal MT, Spanish Working Group for the Study of Mortality among Drug Users (2014) Mortality risk factors and excess mortality in a cohort of cocaine users admitted to drug treatment in Spain. Journal of Substance Abuse Treatment, 46(2): 219-226. DOI: 10.1016/j.jsat.2013.07.001. PMID: 24035555.

Dhani A (2014) Seizures of drugs in England and Wales, 2013/14. Home Office Statistical Bulletin 03/14. 30 October. London: Home Office Statistical Unit. Available at: https://www.gov.uk/government/uploads/system/uploads/attachment data/file/367761/hosb031 4.pdf (accessed 20 September 2015). Seizures of drugs in England and Wales, 2013/14: data tables. Available at: https://www.gov.uk/government/uploads/system/uploads/attachment data/file/367335/hosb031 4-tabs.ods (accessed 20 September 2015). 
DHSSPSNI (2014) Statistics from the Northern Ireland Drug Misuse Database: 1 April 2013 - 1 March 2014. October. Belfast: Department of Health, Social Services and Public Safety. Available at: http://www.dhsspsni.gov.uk/index/statistics/dmd-2013-14.pdf (accessed 16 September 2015).

EMCDDA (2007) Cocaine and crack cocaine: a growing public health issue, Selected issue 2007, European Monitoring Centre for Drugs and Drug Addiction, Lisbon. Available at: http://www.emcdda.europa.eu/attachements.cfm/att 44748 EN TDSI07002ENC.pdf (accessed 16 September 2015).

EMCDDA (2010) The Drug-related deaths (DRD) standard protocol, version 3.2., European Monitoring Centre for Drugs and Drug Addiction, Lisbon. Available at: http://www.emcdda.europa.eu/attachements.cfm/att 107408 EN DRD\%20Standard\%20Protoc ol\%20version\%203.2.pdf (accessed 16 September 2015).

EMCDDA (2011) Annual report 2011 - the state of the drugs problem in Europe, European Monitoring Centre for Drugs and Drug Addiction, Lisbon. Available at: http://www.emcdda.europa.eu/attachements.cfm/att 143743 EN EMCDDA AR2011 EN.pdf (accessed 16 September 2015).

http://mc.manuscriptcentral.com/jop 
EMCDDA (2013a) European Drug Report 2013: Trends and developments. 28 May. European Monitoring Centre for Drugs and Drug Addiction, Lisbon. Available at: http://www.emcdda.europa.eu/attachements.cfm/att 213154 EN TDAT13001ENN1.pdf (accessed 16 September 2015).

EMCDDA (2013b) Emergency health consequences of cocaine use in Europe. Perspectives on drugs. 28 May. European Monitoring Centre for Drugs and Drug Addiction, Lisbon. Available at: http://www.emcdda.europa.eu/topics/pods/cocaine-related-emergencies (accessed 16 September 2015).

EMCDDA (2013c) Statistical bulletin 2013. 28 May. European Monitoring Centre for Drugs and Drug Addiction, Lisbon. Available at: http://www.emcdda.europa.eu/stats13, http://www.emcdda.europa.eu/stats13\#display:/stats13/drdtab108 (accessed 16 September 2015).

EMCDDA (2014) Emergency health consequences of cocaine use in Europe. A review of the monitoring of drug-related acute emergencies in 30 European countries. April. European Monitoring Centre for Drugs and Drug Addiction, Lisbon. Available at: http://www.emcdda.europa.eu/attachements.cfm/att 226037 EN Cocaine emergencies rep ort final.pdf (accessed 16 September 2015).

EMCDDA (2015) European Drug Report - Trends and Developments 2015. 4 June. European Monitoring Centre for Drugs and Drug Addiction, Lisbon. Available at: http://www.emcdda.europa.eu/edr2015 (accessed 16 September 2015). 
Evrard I, Legleye S and Cadet-Taïrou A (2010) Composition, purity and perceived quality of street cocaine in France. International Journal of Drug Policy. 21(5):399-406. DOI: 10.1016/j.drugpo.2010.03.004. PubMed PMID: 20378323.

Ghodse AH, Corkery J, Oyefeso A and Schifano F (2008) Drug related deaths in the UK. Annual Report 2008. London: International Centre for Drug Policy, St George's, University of London. Available at:

http://www.sgul.ac.uk/images/docs/idcp \%20pdfs/National\%20programme\%20on\%20substance \%20abuse\%20deaths/np-SAD Annual Report 2008.pdf (accessed 16 September 2015).

Ghodse H, Corkery J, Ahmed K, Naidoo V, Oyefeso A and and Schifano F (2010) Drug-related deaths in the UK: Annual Report 2010, Drug-related deaths reported by Coroners in England, Wales, Northern Ireland, Guernsey, Jersey and the Isle of Man; Police forces in Scotland; \& the Northern Ireland Statistics and Research Agency — Annual Report January-December 2009. London: International Centre for Drug Policy, St George's University of London. 24 August 2010. Available at:

http://www.sgul.ac.uk/images/docs/idcp\%20pdfs/National\%20programme\%20on\%20substance \%20abuse\%20deaths/np-SAD 11th annual report 2010 FinalCopy.pdf (accessed 16 September 2015).

Gray JD (1993) Medical consequences of cocaine. Canadian Family Physician. 39:1975-6, 1979-81. PubMed PMID: 8106032. 
Hollinger MA (1993) Drug-induced lung toxicity. International Journal of Toxicology. 12(1):3147. DOI:10.3109/10915819309140620.

Home Office (2012) Drug Misuse Declared: Findings from the 2011/12 Crime Survey for England and Wales (2 ${ }^{\text {nd }}$ Edition). July. London: Home Office. Available at: https://www.gov.uk/government/uploads/system/uploads/attachment data/file/147938/drugsmisuse-dec-1112-pdf.pdf (accessed 16 September 2015).

Home Office (2013) Drug misuse: Findings for the 2012/13 Crime Survey for England and Wales. July. London: Home Office Statistics Unit. Available at: https://www.gov.uk/government/uploads/system/uploads/attachment data/file/225122/Drugs Misuse201213.pdf (accessed 16 September 2015).

Howard RE, Hueter DC and Davis GJ (1985) Acute myocardial infarction following cocaine abuse in a young woman with normal coronary arteries. Journal of the American Medical Association. 254(1):95-96. PubMed PMID: 3999356.

HSCIC (2013) Special feature: a linked dataset to investigate mortality of people with severe illness, pp. 33-42 in Mental Health Bulletin: Annual report from MHMDS returns - England 2011-12, initial national figures. 19 February. Leeds: Health and Social Care Information Service. Available at: http://www.hscic.gov.uk/catalogue/PUB10347/ment-heal-bull-mhmds-anua-retu-2011-12bulletin.pdf. (accessed 16 September 2015). 
ISD Scotland (2014) Scottish Drugs Misuse Database (SDMD) NHS Health Board - overview of initial assessments for Specialist Drug Treatment 2012/13. 24 June. Edinburgh: Information Services Division Scotland. Available at: http://www.isdscotland.org/Health-Topics/Drugs-andAlcohol-Misuse/Publications/2014-06-24/2014-06-24-SDMD-Report.pdf (accessed 16 September 2015).

Karch SB (2005) Cocaine cardiovascular toxicity. Southern Medical Journal. 98(8):794-799. PubMed PMID: 16144174.

Kehrer JP and Kacew S (1985) Systematically applied chemicals that damage lung tissue. Toxicology. 35(4):251-293. PubMed PMID: 3160139.

King LA (1997) Drug content of powders and other illicit preparations in the UK. Forensic Science International. 85(2):135-147. DOI: 10.1016/S0379-0738(96)02089-0

Knuepfer MM (2003) Cardiovascular disorders associated with cocaine use: myths and truths. Pharmacology \& Therapeutics. 97(3):181-222. PubMed PMID: 12576134.

Kozor R, Grieve SM, Buchholz S, Kaye S, Darke S, Bhindi R and Figtree GA (2014) Regular cocaine use is associated with increased systolic blood pressure, aortic stiffness and left ventricular mass in young otherwise healthy individuals. PLoS One. 9(4):e89710. DOI: 10.1371/journal.pone.0089710. eCollection 2014. PubMed PMID: 24717541; PubMed Central PMCID: PMC3981670. 
Lader D (ed.) (2015) Drug misuse: findings from the 2014 to 2015 Crime Survey for England and Wales. Statistical Bulletin 03/15. 23 July. London: Home Office Statistics Unit. Available at: https://www.gov.uk/government/uploads/system/uploads/attachment data/file/450181/drugmisuse-1415.pdf (accessed 20 September 2015).

Tables for Drug misuse: findings from the 2014 to 2015 CSEW. Available at: https://www.gov.uk/government/uploads/system/uploads/attachment data/file/448083/drugmisuse-1415-tabs.xls (accessed 20 September 2015).

Lahti RA, Korpi H and Vuori E (2009) Blood-positive illicit-drug findings: implications for causeof-death certification, classification and coding. Forensic Science International. 187(1-3):8-14. DOI: 10.1016/j.forsciint.2009.02.007. PubMed PMID: 19303228.

LGC (2015) Class A - National drugs intelligence bulletin: Q3/4 2014. Teddington, Middx: LGC Ltd. Liaudet L, Calderari B and Pacher P (2014) Pathophysiological mechanisms of catecholamine and cocaine-mediated cardiotoxicity. Heart Failure Reviews. 19(6):815-824. DOI: 10.1007/s10741-014-9418-y

Mena G, Giraudon I, Álvarez E, Corkery JM, Matias J, Grasaasen K, Llorens N, Griffiths P and Vicente J (2013) Cocaine-related health emergencies in Europe: A review of sources of information, prevalence and implications for service development. European Addiction Journal. 19(2):74-81. DOI: 10.1159/000341719. PubMed PMID: 23151969. 
NISRA (2016) Drug-Related Deaths and Deaths due to Drug Misuse registered in Northern Ireland (2005-2015). 25 October 2016. Belfast: Northern Ireland Statistics \& Research Agency. Available at: http://www.nisra.gov.uk/archive/demography/publications/drug deaths/Drug Tables 15.xls (accessed 31 October 2016).

NRS (2015) Drug-Related Deaths in Scotland in 2014. Edinburgh: National Records of Scotland. 25 August 2015. Available at:

http://www.gro-scotland.gov.uk/files//statistics/drug-related-deaths/drd14/drugs-related-deaths2014.pdf

http://www.gro-scotland.gov.uk/statistics-and-data/statistics/statistics-by-theme/vitalevents/deaths/drug-related-deaths-in-scotland/2014/list-of-tables-and-figures (accessed 16 September 2015).

NRS (2016) Drug-Related Deaths in Scotland in 2015. Edinburgh: National Records of Scotland. 17 August 2016. Available at: http://www.nrscotland.gov.uk/files//statistics/drugrelated-deaths/15/drugs-related-deaths-2015.pdf http://www.nrscotland.gov.uk/files//statistics/drug-related-deaths/15/2015-drugs-related-alltabsfigs.xlsx (accessed 31 October 2016).

ONS (2014) Deaths related to drug poisoning in England and Wales, 2013. Statistical Bulletin. 3 September 2014. Newport, Gwent: Office for National Statistics. Available with accompanying spreadsheets at: http://www.ons.gov.uk/ons/dcp171778 375498.pdf 
http://www.ons.gov.uk/ons/rel/subnational-health3/deaths-related-to-drug-poisoning/englandand-wales---2013/rft---table-1.xls (accessed 16 September 2015).

ONS (2016) Deaths related to drug poisoning in England and Wales, 2015. Statistical Bulletin. 9 September 2016. Newport, Gwent: Office for National Statistics. Available with accompanying spreadsheets at: https://www.ons.gov.uk/peoplepopulationandcommunity/birthsdeathsandmarriages/deaths/bullet ins/deathsrelatedtodrugpoisoninginenglandandwales/2015registrations https://www.ons.gov.uk/file?uri=/peoplepopulationandcommunity/birthsdeathsandmarriages/dea $\underline{\text { ths/datasets/deathsrelatedtodrugpoisoningenglandandwalesreferencetable/current/rftdrugs2015 }}$ .xls (accessed 31 October 2016).

Oyefeso A, Schifano F, Ghodse H, Cobain K, Dryden R, Corkery J. Fatal injuries while under the influence of psychoactive drugs: a cross-sectional exploratory study in England. BMC Public Health. 2006 Jun 6;6:148. PubMed PMID: 16756659; PubMed Central PMCID: PMC1523208.

Parker RB, Williams CL, Laizure SC, Mandrell TD, LaBranche GS and Lima JJ (1996) Effects of ethanol and cocaethylene on cocaine pharmacokinetics in conscious dogs. Drug Metabolism and Disposition. 24(8):850-3. PubMed PMID: 8869818.

Pavarin RM (2013) Mortality risk for cocaine abusers in relation to heroin use: a follow-up study. Substance Use \& Misuse. 48(9):702-10. DOI: 10.3109/10826084.2013.786731. PubMed PMID: 23607671. 
Pavarin R, Lugoboni F, Methewson S, Ferrari AM, Guizzardi G and Quaglio G (2011) Cocainerelated medical and trauma problems: a consecutive series of 743 patients from a multicentre study in Italy. European Journal of Emergency Medicine. 18(4):208-214. DOI:

10.1097/MEJ.0b013e3283440f25

Pawlik E and Mahler H (2013) Smoke analysis of adulterated drug preparations. Toxichem Krimtech. 78(Spec Issue):200-210.

Pawlik E, Mahler H, Hartung B, Plässer G and Daldrup T (2015) Drug-related death: adulterants from cocaine preparations in lung and tissue. Forensic Science International. 249:294-303.

DOI: 10.1016/j.forsciint.2015.02.006. PubMed PMID: 25747329.

PHE (2014) Adult Drug Statistics from the National Drug Treatment Monitoring System (NDTMS) 1 April 2013 to 31 March 2014. London: Public Health England. Available at: http://www.nta.nhs.uk/uploads/adult-drug-statistics-from-the-national-drug-treatment-monitoringsystem-2013-14.pdf (accessed 16 September 2015).

Rajs J, and Fugelstad A (1999) Detection of Cannabis in Victims of Violent Death in Stockholm (1987-1994). pp. 683-9, in Marijuana and Medicine. Nahas GG, Sutin KM, Harvey DJ and Agurell S (Eds.) Humana Press, Totowa, NJ.

Roe S and Man L (2006) Drug Misuse Declared: Findings from the 2005/06 British Crime Survey - England and Wales. October. London: Home Office. Available at: 
http://webarchive.nationalarchives.gov.uk/20110220105210/rds.homeoffice.gov.uk/rds/pdfs06/h osb1506.pdf (accessed 16 September 2015).

Rooney CIF, and Smith SK (2000) Implementation of ICD-10 for mortality data in England and Wales from January 2001. Health Statistics Quarterly 8: 41-50. - Available at: http://webarchive.nationalarchives.gov.uk/20160105160709/http://www.ons.gov.uk/ons/rel/hsq/h ealth-statistics-quarterly/no--8--winter-2000/implementation-of-icd-10-for-mortality-data-inengland-and-wales-from-january-2001.pdf (accessed 26 March 2017).

Santos S, Brugal MT, Barrio G, Castellano Y, Domingo-Salvany A, Espelt A, Bravo MJ, de la Fuente L and ITINERE Project Group (2012) Assessing the effects of cocaine and alcohol use on the risk of adverse acute cocaining intoxication. Drug and Alcohol Review. 31(4):439-446.

DOI: 10.1111/j.1465-3362.2011.00411.X. PubMed PMID: 22260083.

Schifano F (2001) Nuove tendenze in tema di tossicodipendenza: le droghe sintetiche. Aspetti epidemiologici, clinici e di prevenzione [New trends in drug addiction: synthetic drugs. Epidemiological,clinical and preventive issues]. Epidemiologia e Psichiatria Sociale. 10(2):63-70. Italian. DOI: 10.1017/S1121189X00005121. PubMed PMID: 11526795.

Schifano F (2004) A bitter pill? Overview of ecstasy (MDMA; MDA) related fatalities.

Psychopharmacology (Berlin). 173(3-4):242-8. PubMed PMID: 14673568.

Schifano F and Corkery J (2006) Decessi ed altri indicatori chiave del consume di cocaine nel Regno Unito (1990-2004) [Deaths and other key indicators of consumption of cocaine in the UK 
(1990-2004]. In Serpelloni G, Macchia T and Gerra G (eds) Cocaina: Manuale di aggiornamento tecnico scientifico [Cocaine: Manual of Scientific Technical Update]. January 2006. Verona, Italy: Dipartimento Nazionale per le Politiche Antidroga, 87-101. ISBN: 88-95149-00-9

Schifano F and Corkery J (2008) Cocaine/crack cocaine consumption, treatment demand,seizures, related offences, prices, average purity levels and deaths in the UK (1990 2004). Journal of Psychopharmacology. 22(1):71-9. DOI: 10.1177/0269881107079170. PubMed PMID: 18187534.

Schifano F, Corkery J, Naidoo V, Oyefeso A and Ghodse H (2010) Overview of amphetaminetype stimulant mortality data--UK, 1997-2007. Neuropsychobiology. 61(3):122-30. DOI: 10.1159/000279302. PubMed PMID: 20110737.

Schifano F, Orsolini L, Papanti GD and Corkery JM (2015) Novel psychoactive substances of interest for psychiatry. World Psychiatry. 14(1):15-26. DOI: 10.1002/wps.20174.

Schneider S and Meys F (2011) Analysis of illicit cocaine and heroin samples seized in Luxembourg from 2005-2010. Forensic Science International. 212(1-3):242-246. DOI: 10.1016/j.forsciint.2011.06.027. PubMed PMID: 21767923.

Shapiro H (2002) From Chaplin to Charlie - cocaine, Hollywood and the movies. Drugs: education, prevention and policy. 9(2):133-141. DOI: 10.1080/0968760110119161 
Stephens BG, Jentzen JM, Karch S, Wetli CV and Mash DC (2004) National Association of Medical Examiners Position Paper on the Certification of Cocaine-Related Deaths. The American Journal of Forensic Medicine and Pathology. 25(1):11-13. PubMed PMID: 15075681. Available at: http://charlydmiller.com/LIB04/2004namecocainedeaths.pdf (accessed 16 September 2015).

Stephenson G and Richardson A (2014) New Psychoactive Substances in England - A review of the evidence. 30 October, London: Crime and Policing Analysis Unit, Home Office Science. Available at:

https://www.gov.uk/government/uploads/system/uploads/attachment data/file/368587/NPSevid enceReview.pdf (accessed 6 November 2016).

Vasica G and Tennant CC (2002) Cocaine use and cardiovascular complications. Medical Journal of Australia. 177(5): 260-262. PubMed PMID: 12197823.

Warner M, Hedegaard H and Chen L-H (2014) Trends in drug-poisoning deaths involving opioid analgesics and heroin: United States, 1999-2012. December. NCHS Health E-Stat, Available at: http://stacks.cdc.gov/view/cdc/32919/cdc 32919 DS1.pdf (accessed on 3 April 2016).

Webb L, Oyefeso A, Schifano F, Cheeta S, Pollard M and Ghodse AH (2003) Cause and manner of death in drug-related fatality: an analysis of drug related deaths recorded by coroners in England and Wales in 2000. Drug and Alcohol Dependence. 72(1):67-74. PubMed PMID: 14563544. 
Weichert I (2011) Acute management of cocaine-associated methaemoglobinaemia. Case Reports in Medicine. 2011. Article ID 136396. 3 pages. DOI: 10.1155/2011/136396. PubMed PMID: 22242027; PubMed Central PMCID: PMC3254234.

Welsh Government \& NHS Wales (2014) Treatment Data - Substance Misuse in Wales 201314. 30 October. Cardiff: Welsh Government \& NHS Wales Informatics Service. Available at: http://gov.wales/docs/dhss/report/141029substancemisuseinwales1314en.pdf (accessed 16 September 2015).

Whiteford HA, Degenhardt L, Rehm J, Baxter AJ, Ferrari AJ, Erskine HE, Charlson FJ, Norman RE, Flaxman AD, Johns N, Burstein R, Murray CJ and Vos T (2013) Global burden of disease attributable to mental and substance use disorders: findings from the Global Burden of Disease Study 2010. Lancet. 382(9904):1575-86. DOI: 10.1016/S0140-6736(13)61611-6. PubMed PMID: 23993280.

WHO (1992) The ICD-10 Classification of Mental and Behavioural Disorders. Clinical descriptions and diagnostic guidelines, Geneva: World Health Organization. Available at: http://www.who.int/classifications/icd/en/ (accessed 16 September 2015).

WHO (2010) ICD-10 2010 online (Current version). Available at: http://apps.who.int/classifications/icd10/browse/2010/en (accessed 16 September 2015). 
Winstock A and Schifano F (2009) Disorders relating to the use of ecstasy, other 'party drugs' and khat.In: Gelder M, Andreasen N, Lopez-lbor JJ and Geddes J (eds) New Oxford Textbook of Psychiatry. Oxford: Oxford University Press, 541-546.

Wirl C (2010) Inventory of the national Special Mortality Registries in Europe, and description of the core data available. Gesundheit Österreich GMBH - Geschäftsbereich Öbig' (EMCDDA contract CT.08.EPI.083.1.0). Available at:

http://www.emcdda.europa.eu/attachements.cfm/att 107397 EN Report Inventory SMR\%20 final.pdf (accessed 25 May 2015).

Wunsch, M.J., Nuzzo, P.A., Behonick, G., Massello, W., Walsh, S.L. (2013). MethadoneRelated Overdose Deaths in Rural Virginia: 1997 to 2003. Journal of Addiction Medicine: July/August, 7(4): 223-229. doi: 10.1097/ADM.0b013e31828c4d33. Available at: http://journals.Iww.com/journaladdictionmedicine/Abstract/2013/07000/Methadone Related Ov erdose Deaths in Rural.1.aspx 
Figure 1: Medical Certificate of Death used in England and Wales 
Figure 2: Trends in UK cocaine-related DRDs (any mention): actual numbers in 19982012, based on SMR and GMR and reported for cocaine mentioned in the cause of death (COD), or identified in post mortem (PM)

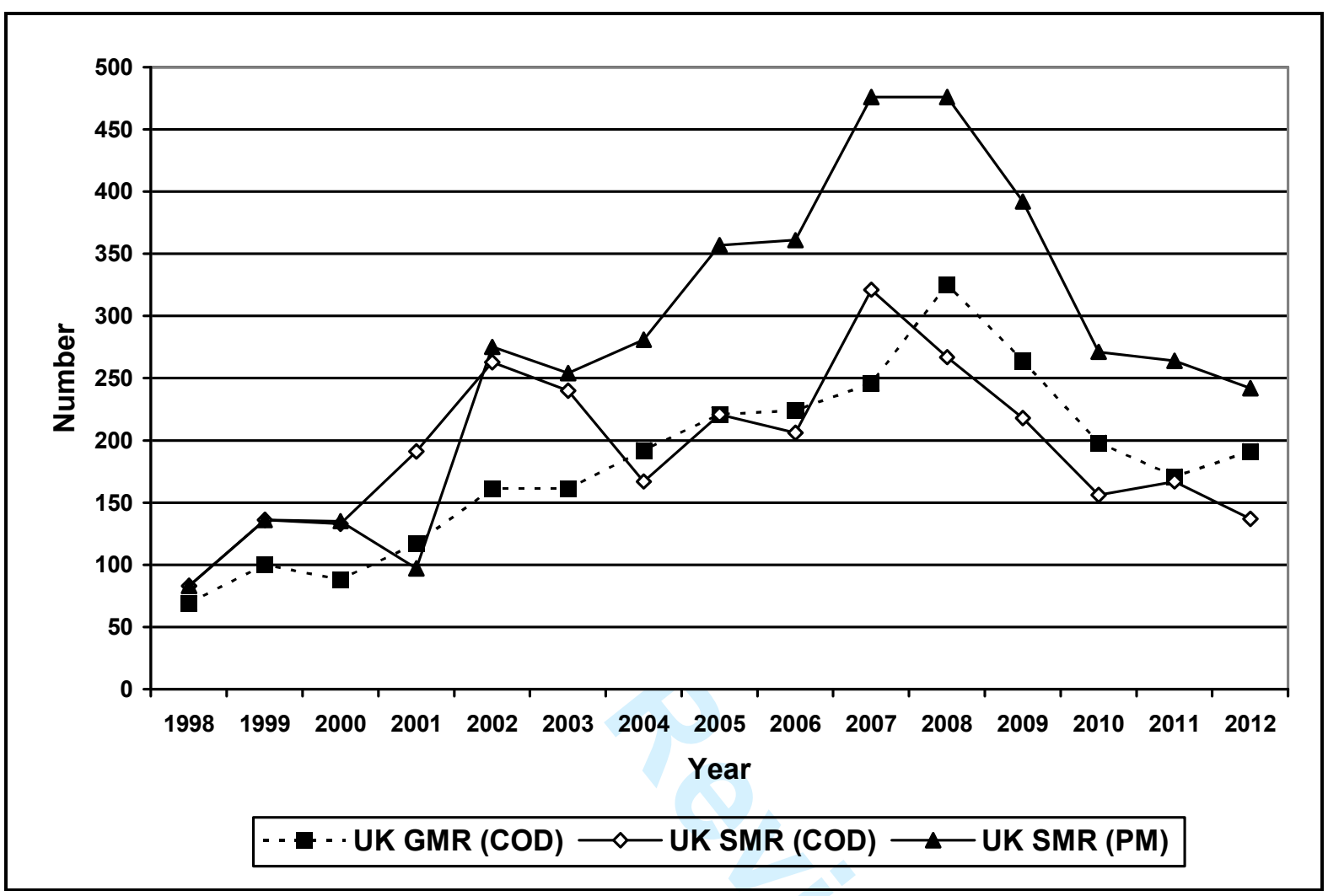


Figure 3: Results of Joinpoint analyses for UK cocaine-related death trends 1998-2012

GMR Cause of Death Any Mention

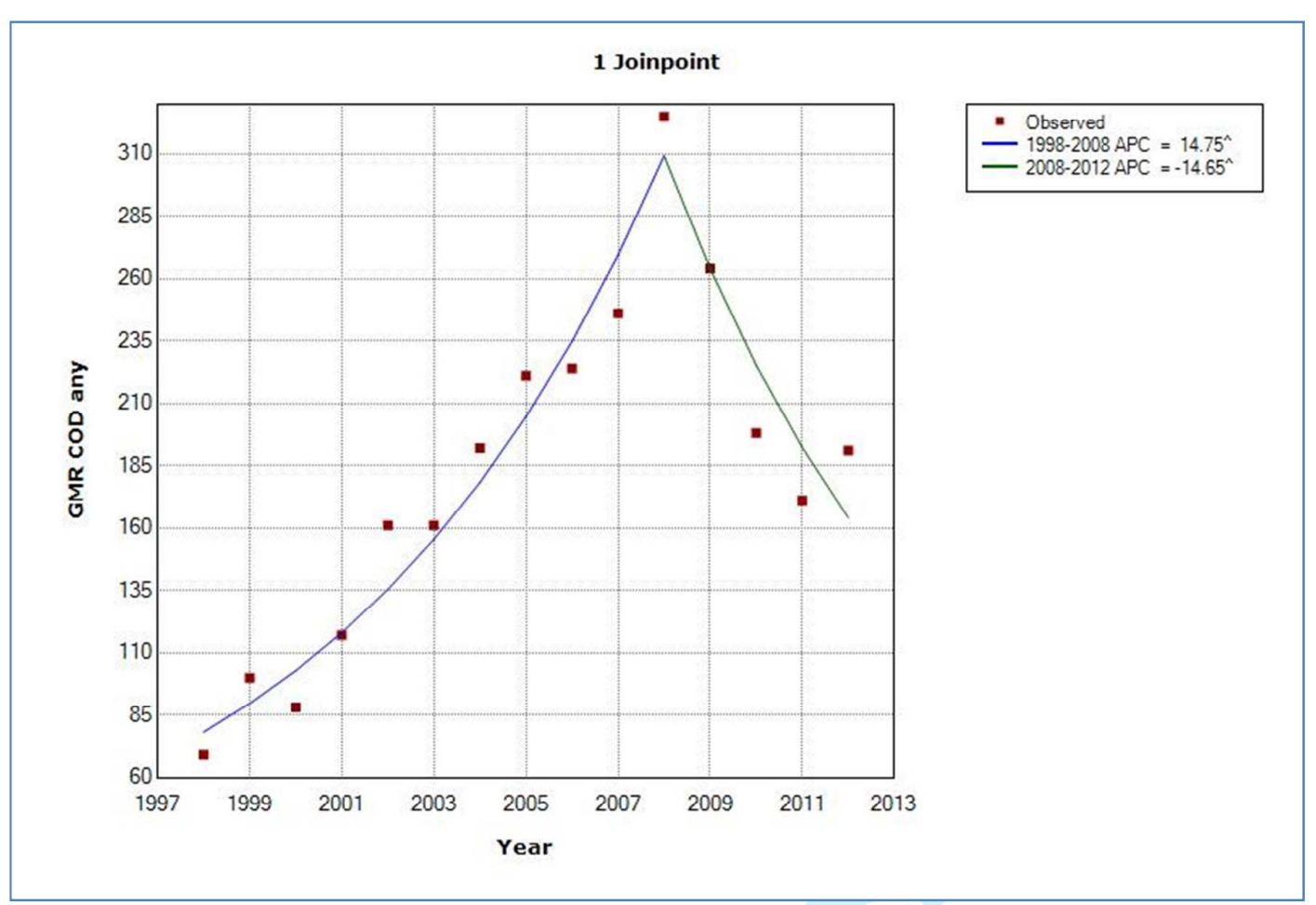

\begin{tabular}{|c|c|c|c|c|c|c|c|c|}
\hline Graph Data & Model Estimates & \begin{tabular}{l|l} 
Trends & Mod
\end{tabular} & Selection & & & & & \\
\hline & & & & ated Joinp & & & & \\
\hline Joinpoint & Estimate & Lower $\mathrm{Cl}$ & Upper Cl & & & & & \\
\hline 1 & 2008 & 2006 & 2009 & & & & & \\
\hline & & & Annua & rcent Char & (APC) & & & \\
\hline Segment & $\begin{array}{l}\text { Lower } \\
\text { Endpoint }\end{array}$ & $\begin{array}{l}\text { Upper } \\
\text { Endpoint }\end{array}$ & APC & Lower Cl & Upper CI & $\begin{array}{c}\text { Test } \\
\text { Statistic }\end{array}$ & P-Value & \\
\hline 1 & 1998 & 2008 & $14.7^{\curvearrowright}$ & 11.4 & 18.2 & 10.4 & 0.0 & \\
\hline 2 & 2008 & 2012 & $-14.6^{\wedge}$ & -24.3 & -3.8 & -2.9 & 0.0 & \\
\hline he Annual & rcent Change (AP & is significanth & ferent from ze & alpha $=0.05$ & & & & \\
\hline & & & Average Av & Percent C & ge (AAPC) & & & \\
\hline Cohort & Range & $\begin{array}{l}\text { Lower } \\
\text { Endpoint }\end{array}$ & $\begin{array}{l}\text { Upper } \\
\text { Endpoint }\end{array}$ & AAPC & Lower $\mathrm{Cl}$ & Upper Cl & $\begin{array}{c}\text { Test } \\
\text { Statistic }\end{array}$ & P-Value \\
\hline & Full Rance & 1998 & 2012 & $5.4^{\wedge}$ & 1.8 & 9.2 & 2.9 & 0.0 \\
\hline
\end{tabular}


GMR Cause of Death Sole Mention

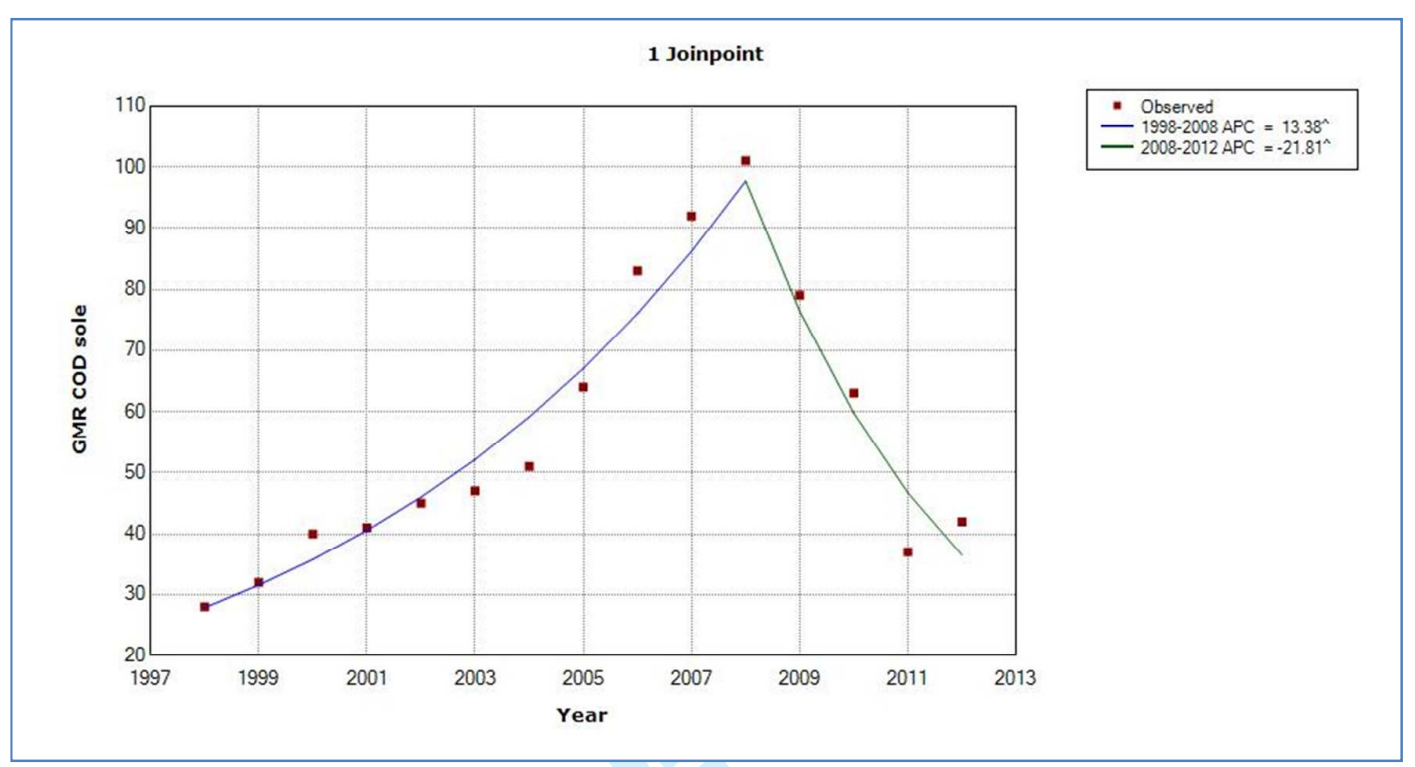

\begin{tabular}{|c|c|c|c|c|c|c|c|c|}
\hline Graph Data & Model Estimates & Trends Moc & Selection & & & & & \\
\hline \multicolumn{9}{|c|}{ Estimated Joinpoints } \\
\hline Joinpoint & Estimate & Lower Cl & Upper Cl & & & & & \\
\hline 1 & 2008 & 2007 & 2009 & & & & & \\
\hline \multicolumn{9}{|c|}{ Annual Percent Change (APC) } \\
\hline Segment & $\begin{array}{l}\text { Lower } \\
\text { Endpoint }\end{array}$ & $\begin{array}{l}\text { Upper } \\
\text { Endpoint }\end{array}$ & APC & Lower Cl & Upper Cl & $\begin{array}{c}\text { Test } \\
\text { Statistic }\end{array}$ & P-Value & \\
\hline \multirow{2}{*}{$\begin{array}{l}1 \\
2\end{array}$} & 1998 & 2008 & $13.4^{\wedge}$ & 10.2 & 16.7 & 9.7 & 0.0 & \\
\hline & 2008 & 2012 & $-21.8^{\wedge}$ & -30.4 & -12.1 & -4.7 & 0.0 & \\
\hline \multicolumn{9}{|c|}{${ }^{\wedge}$ The Annual Percent Change (APC) is significantly different from zero at alpha $=0.05$} \\
\hline \multicolumn{9}{|c|}{ Average Annual Percent Change (AAPC) } \\
\hline \multirow[t]{2}{*}{ Cohort } & Range & $\begin{array}{c}\text { Lower } \\
\text { Endpoint }\end{array}$ & $\begin{array}{c}\text { Upper } \\
\text { Endpoint }\end{array}$ & AAPC & Lower $\mathrm{Cl}$ & Upper Cl & $\begin{array}{c}\text { Test } \\
\text { Statistic }\end{array}$ & P-Value \\
\hline & Full Ranoe & 1998 & 2012 & 2.0 & -1.5 & 5.5 & 1.1 & 0.3 \\
\hline
\end{tabular}

44

45

46

47

48

49

50

51

52

53

54

55

56 
SMR Cause of Death Any Mention

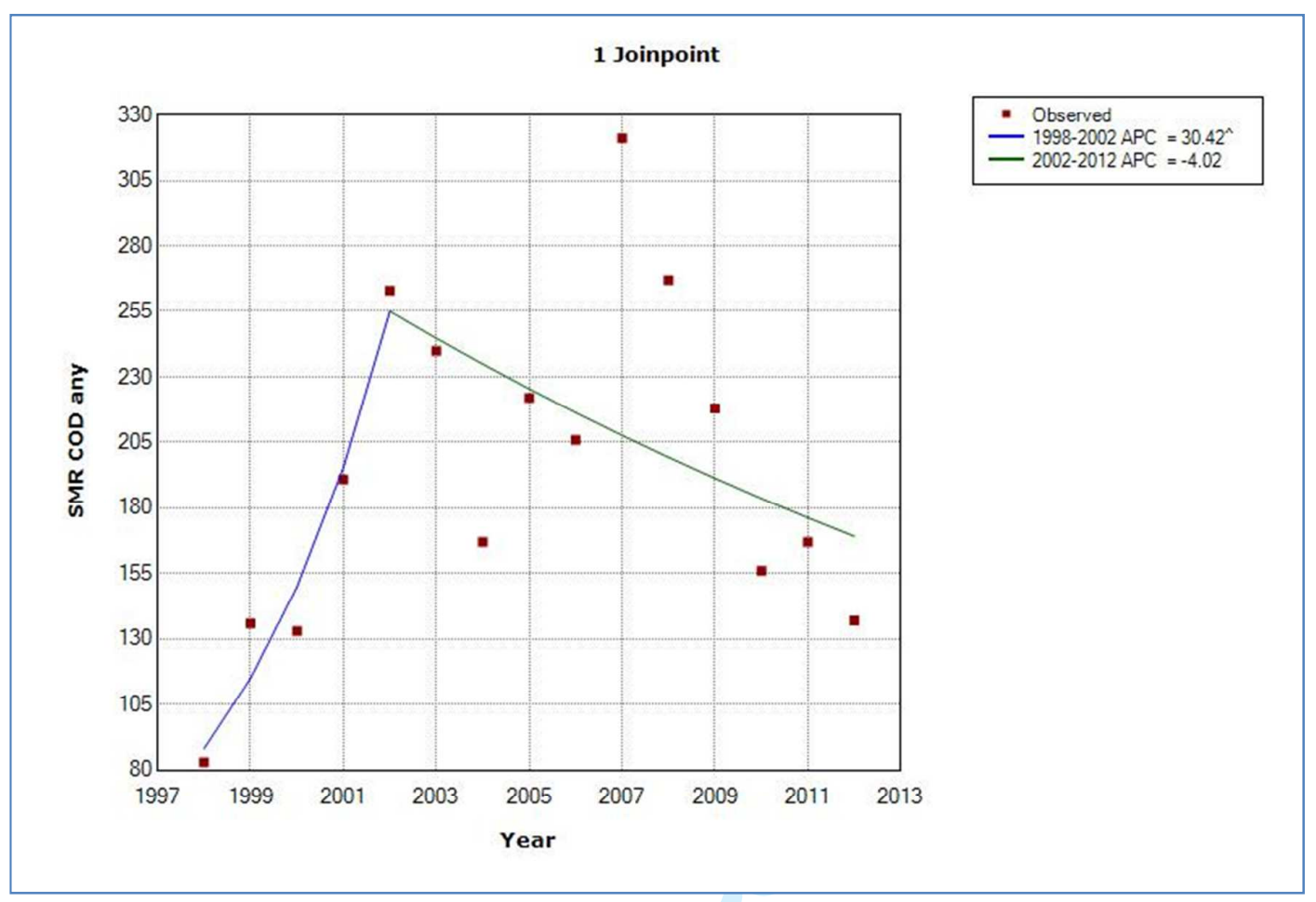

\begin{tabular}{|c|c|c|c|c|c|c|c|c|}
\hline Graph Data & Model Estimates & Trends Mo & ielection & & & & & \\
\hline \multicolumn{9}{|c|}{ Estimated Joinpoints } \\
\hline Joinpoint & Estimate & Lower $\mathrm{Cl}$ & Upper Cl & & & & & \\
\hline 1 & 2002 & 2000 & 2009 & & & & & \\
\hline \multicolumn{9}{|c|}{ Annual Percent Change (APC) } \\
\hline Segment & $\begin{array}{c}\text { Lower } \\
\text { Endpoint }\end{array}$ & $\begin{array}{l}\text { Upper } \\
\text { Endpoint }\end{array}$ & APC & Lower $\mathrm{Cl}$ & Upper Cl & $\begin{array}{c}\text { Test } \\
\text { Statistic }\end{array}$ & P-Value & \\
\hline 1 & 1998 & 2002 & $30.4^{\wedge}$ & 3.7 & 64.1 & 2.6 & 0.0 & \\
\hline 2 & 2002 & 2012 & -4.0 & -9.3 & 1.6 & -1.6 & 0.1 & \\
\hline${ }^{\wedge}$ The Annual F & rcent Change (AP & is significant & ferent from ze & alpha $=0.05$ & & & & \\
\hline & & & Average A & I Percent C & ge (AAPC) & & & \\
\hline Cohort & Range & $\begin{array}{l}\text { Lower } \\
\text { Endpoint }\end{array}$ & $\begin{array}{l}\text { Upper } \\
\text { Endpoint }\end{array}$ & AAPC & Lower $\mathrm{Cl}$ & Upper Cl & $\begin{array}{c}\text { Test } \\
\text { Statistic }\end{array}$ & P-Value \\
\hline
\end{tabular}


SMR Cause of Death Sole Mention

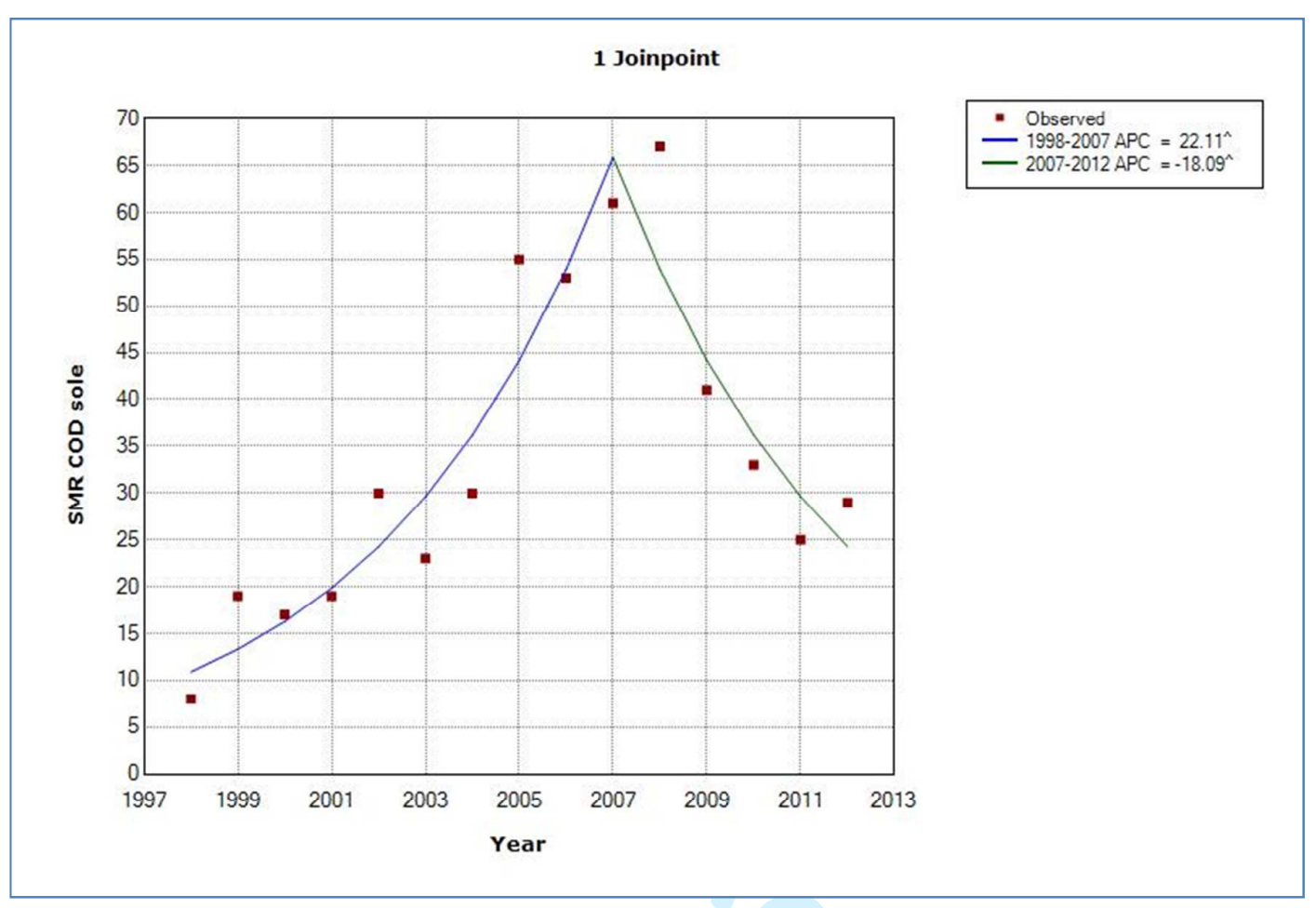

\begin{tabular}{|c|c|c|c|c|c|c|c|c|}
\hline Graph Data & Model Estimates & Trends Moc & Selection & & & & & \\
\hline \multicolumn{9}{|c|}{ Estimated Joinpoints } \\
\hline Joinpoint & Estimate & Lower $\mathrm{Cl}$ & Upper Cl & & & & & \\
\hline 1 & 2007 & 2005 & 2009 & & & & & \\
\hline \multicolumn{9}{|c|}{ Annual Percent Change (APC) } \\
\hline Segment & $\begin{array}{l}\text { Lower } \\
\text { Endpoint }\end{array}$ & $\begin{array}{l}\text { Upper } \\
\text { Endpoint }\end{array}$ & APC & Lower Cl & Upper Cl & $\begin{array}{c}\text { Test } \\
\text { Statistic }\end{array}$ & P-Value & \\
\hline 1 & 1998 & \multirow{2}{*}{$\begin{array}{l}2007 \\
2012\end{array}$} & $22.1^{\wedge}$ & 14.2 & 30.5 & 6.7 & 0.0 & \\
\hline 2 & 2007 & & $-18.1^{\wedge}$ & -30.4 & -3.6 & -2.7 & 0.0 & \\
\hline \multicolumn{9}{|c|}{${ }^{\wedge}$ The Annual Percent Change (APC) is significantly different from zero at alpha $=0.05$} \\
\hline \multicolumn{9}{|c|}{ Average Annual Percent Change (AAPC) } \\
\hline Cohort & Range & $\begin{array}{l}\text { Lower } \\
\text { Endpoint }\end{array}$ & $\begin{array}{l}\text { Upper } \\
\text { Endpoint }\end{array}$ & AAPC & Lower $\mathrm{Cl}$ & Upper Cl & $\begin{array}{c}\text { Test } \\
\text { Statistic }\end{array}$ & P-Value \\
\hline
\end{tabular}

http://mc.manusch4ptcentral.com/jop 
SMR Post Mortem Toxicology Any Mention

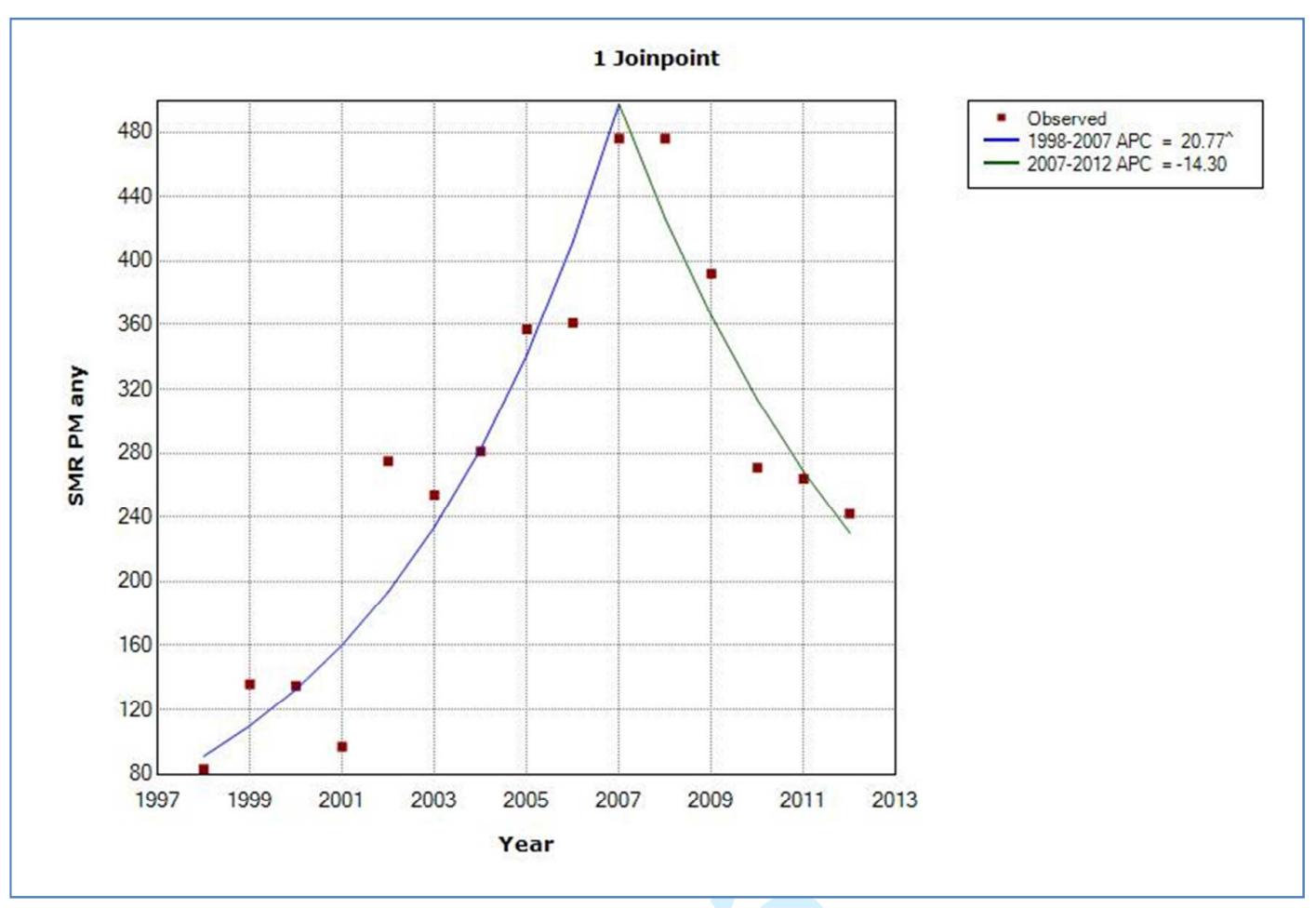

\begin{tabular}{|c|c|c|c|c|c|c|c|c|c|}
\hline Graph & Data & Model Estimates & Trends Moc & Selection & & & & & \\
\hline \multicolumn{10}{|c|}{ Estimated Joinpoints } \\
\hline \multicolumn{2}{|c|}{ Joinpoint } & Estimate & Lower $\mathrm{Cl}$ & Upper Cl & & & & & \\
\hline & 1 & 2007 & 2005 & 2009 & & & & & \\
\hline \multicolumn{10}{|c|}{ Annual Percent Change (APC) } \\
\hline \multicolumn{2}{|c|}{ Segment } & $\begin{array}{l}\text { Lower } \\
\text { Endpoint }\end{array}$ & $\begin{array}{l}\text { Upper } \\
\text { Endpoint }\end{array}$ & APC & Lower Cl & Upper Cl & $\begin{array}{c}\text { Test } \\
\text { Statistic }\end{array}$ & P-Value & \\
\hline \multirow{2}{*}{\multicolumn{2}{|c|}{$\begin{array}{l}1 \\
2\end{array}$}} & 1998 & 2007 & $20.8^{\wedge}$ & 13.3 & 28.7 & 6.6 & 0.0 & \\
\hline & & 2007 & 2012 & -14.3 & -26.7 & 0.2 & -2.2 & 0.1 & \\
\hline \multicolumn{10}{|c|}{${ }^{\wedge}$ The Annual Percent Change (APC) is significantly different from zero at alpha $=0.05$} \\
\hline \multicolumn{10}{|c|}{ Average Annual Percent Change (AAPC) } \\
\hline & ohort & Range & $\begin{array}{l}\text { Lower } \\
\text { Endpoint }\end{array}$ & $\begin{array}{c}\text { Upper } \\
\text { Endpoint }\end{array}$ & AAPC & Lower $\mathrm{Cl}$ & Upper Cl & $\begin{array}{c}\text { Test } \\
\text { Statistic }\end{array}$ & P-Value \\
\hline
\end{tabular}


SMR Post Mortem Toxicology Sole Mention

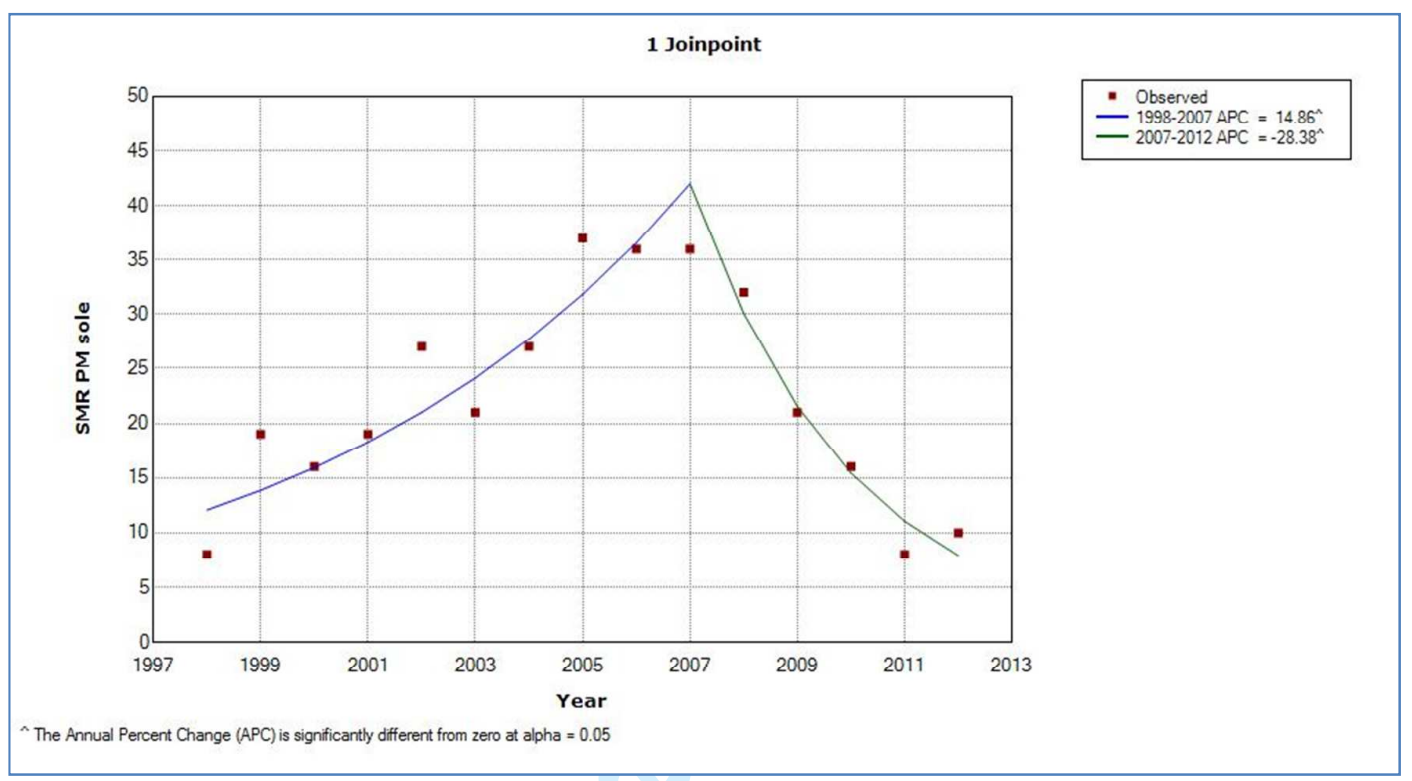

\begin{tabular}{|c|c|c|c|c|c|c|c|c|}
\hline Graph Data & Model Estimates & Trends Mod & Selection & & & & & \\
\hline \multicolumn{9}{|c|}{ Estimated Joinpoints } \\
\hline Joinpoint & Estimate & Lower $\mathrm{Cl}$ & Upper Cl & & & & & \\
\hline 1 & 2007 & 2004 & 2009 & & & & & \\
\hline \multicolumn{9}{|c|}{ Annual Percent Change (APC) } \\
\hline Segment & $\begin{array}{c}\text { Lower } \\
\text { Endpoint }\end{array}$ & $\begin{array}{c}\text { Upper } \\
\text { Endpoint }\end{array}$ & APC & Lower $\mathrm{Cl}$ & Upper Cl & $\begin{array}{c}\text { Test } \\
\text { Statistic }\end{array}$ & P-Value & \\
\hline 1 & 1998 & 2007 & $14.9^{\wedge}$ & 7.5 & 22.7 & 4.7 & 0.0 & \\
\hline 2 & 2007 & 2012 & $-28.4^{\wedge}$ & -39.1 & -15.8 & -4.6 & 0.0 & \\
\hline \multicolumn{9}{|c|}{${ }^{\wedge}$ The Annual Percent Change (APC) is significantly different from zero at alpha $=0.05$} \\
\hline \multicolumn{9}{|c|}{ Average Annual Percent Change (AAPC) } \\
\hline \multirow[t]{2}{*}{ Cohort } & Range & $\begin{array}{l}\text { Lower } \\
\text { Endpoint }\end{array}$ & $\begin{array}{l}\text { Upper } \\
\text { Endpoint }\end{array}$ & AAPC & Lower $\mathrm{Cl}$ & Upper Cl & $\begin{array}{c}\text { Test } \\
\text { Statistic }\end{array}$ & P-Value \\
\hline & Full Rance & 1998 & 2012 & -3.0 & -8.9 & 3.3 & -0.9 & 0.3 \\
\hline
\end{tabular}

http://mc.manusc 6 ptcentral.com/jop 
Table 1: Cocaine-related deaths recorded by UK GMRs and SMR, 1998-2012

\begin{tabular}{|c|c|c|c|c|c|c|c|c|c|c|c|c|c|c|c|c|}
\hline Case definition & 1998 & 1999 & 2000 & 2001 & 2002 & 2003 & 2004 & 2005 & 2006 & 2007 & 2008 & 2009 & 2010 & 2011 & 2012 & Total \\
\hline \multicolumn{17}{|l|}{ GMR cause of death } \\
\hline Any mention & 69 & 100 & 88 & 117 & 161 & 161 & 192 & 221 & 224 & 246 & 325 & 264 & 198 & 171 & 191 & 2728 \\
\hline $\begin{array}{l}\text { Of which as sole } \\
\text { substance }\end{array}$ & 28 & 32 & 40 & 41 & 45 & 47 & 51 & 64 & 83 & 92 & 101 & 79 & 63 & 37 & 42 & 845 \\
\hline Ratio of any/sole & 2.46 & 3.13 & 2.20 & 2.85 & 3.58 & 3.43 & 3.76 & 3.45 & 2.70 & 2.67 & 3.22 & 3.34 & 3.14 & 4.62 & 4.55 & 3.23 \\
\hline $\begin{array}{l}\text { Sole as proportion of any } \\
\text { (\%) }\end{array}$ & 40.6 & 32.0 & 45.5 & 35.0 & 28.0 & 29.2 & 26.6 & 29.0 & 37.1 & 37.4 & 31.1 & 29.9 & 31.8 & 21.6 & 22.0 & 31.0 \\
\hline \multicolumn{17}{|l|}{ SMR cause of death } \\
\hline Any mention & 83 & 136 & 133 & 191 & 263 & 240 & 167 & 222 & 206 & 321 & 267 & 218 & 156 & 167 & 137 & 2907 \\
\hline $\begin{array}{l}\text { Of which as sole } \\
\text { substance }\end{array}$ & 8 & 19 & 17 & 19 & 30 & 23 & 30 & 55 & 53 & 61 & 67 & 41 & 33 & 25 & 29 & 510 \\
\hline Ratio of any/sole & 10.38 & 7.16 & 7.82 & 10.05 & 8.77 & 10.43 & 5.57 & 4.04 & 3.89 & 5.26 & 3.99 & 5.32 & 4.73 & 6.68 & 4.72 & 5.70 \\
\hline $\begin{array}{l}\text { Sole as proportion of any } \\
(\%)\end{array}$ & 9.6 & 14.0 & 12.8 & 9.9 & 11.4 & 9.6 & 18.0 & 24.8 & 25.7 & 19.0 & 25.1 & 18.8 & 21.2 & 15.0 & 21.2 & 17.5 \\
\hline \multicolumn{17}{|c|}{ SMR post mortem mentions } \\
\hline Any mention & 83 & 136 & 135 & 97 & 275 & 254 & 281 & 357 & 361 & 476 & 476 & 392 & 271 & 264 & 242 & 4100 \\
\hline $\begin{array}{l}\text { Of which as sole } \\
\text { substance }\end{array}$ & 8 & 19 & 16 & 19 & 27 & 21 & 27 & 37 & 36 & 36 & 32 & 21 & 16 & 8 & 10 & 333 \\
\hline Ratio of any/sole & 10.38 & 7.16 & 8.44 & 10.37 & 10.19 & 12.10 & 10.41 & 9.65 & 10.03 & 13.60 & 14.88 & 18.67 & 16.94 & 33.00 & 24.20 & 12.31 \\
\hline $\begin{array}{l}\text { Sole as proportion of any } \\
(\%)\end{array}$ & 9.6 & 14.0 & 11.9 & 19.6 & 9.8 & 8.3 & 9.6 & 10.4 & 10.0 & 7.6 & 6.7 & 5.4 & 5.9 & 3.0 & 4.1 & 8.1 \\
\hline
\end{tabular}


Table 2: Summary of Joinpoint analyses for UK cocaine-related deaths, 1998-2012

\begin{tabular}{|c|c|c|c|c|c|c|}
\hline Dataset & Period 1 & APC 1 & Period 2 & APC 2 & $P$ value & $\begin{array}{l}\text { Significant at } \\
0.05 \text { level }\end{array}$ \\
\hline \multicolumn{7}{|c|}{ GMR Cause of Death } \\
\hline Any & $1998-2008$ & $+14.75^{*}$ & $2008-2012$ & $-14.65^{*}$ & 0.3128889 & Yes \\
\hline Sole & $1998-2008$ & $+13.38^{*}$ & $2008-2012$ & $-21.81^{*}$ & 0.4004444 & Yes \\
\hline \multicolumn{7}{|c|}{ SMR Cause of Death } \\
\hline Any & $1998-2002$ & $+30.42^{*}$ & $2002-2012$ & -4.02 & 0.0857778 & Yes \\
\hline Sole & 1998-2007 & $+22.11^{*}$ & $2007-2012$ & $-18.09^{*}$ & 0.8853333 & Yes \\
\hline \multicolumn{7}{|c|}{ SMR Post Mortem toxicology } \\
\hline Any & $1998-2007$ & $+20.77^{*}$ & $2007-2012$ & $-14.30^{*}$ & 0.9742222 & Yes \\
\hline Sole & $1998-2007$ & $+14.90^{*}$ & $2007-2012$ & $-28.40^{*}$ & 0.4102222 & Yes \\
\hline
\end{tabular}


Table 3: Demographic characteristics of UK SMR cocaine-related DRDs 2005-9 
Table 4: Principal underlying causes of death in UK SMR cocaine-related DRDs 2005-9 
Table 5: Principal substances implicated in UK SMR cocaine-related DRDs 2005-9

\begin{tabular}{lrr}
\hline Substance & Number & $\%$ \\
\hline Cocaine - any & 1234 & 100.0 \\
Cocaine - only & 277 & 22.4 \\
Alcohol & 368 & 29.8 \\
Heroin/morphine & 594 & 48.1 \\
Methadone & 192 & 15.6 \\
Other opiates/opioid analgesics & 153 & 12.4 \\
Drugs for anxiety/insomniaHypnotics/sedatives (mostly benzodiazepines) & 220 & 17.8 \\
Drugs for depressionAnti-depressants & 108 & 8.8 \\
Drugs for psychosisAnti-psychotics & 21 & 1.7 \\
Anti-histamines & 8 & 0.6 \\
Anti-epileptics & 3 & 0.2 \\
Anti-Parkinson's & 1 & 0.1 \\
Amphetamines & 56 & 4.5 \\
Ecstasy/MDMA & 62 & 5.0 \\
GHB/GBL & 14 & 1.1 \\
Ketamine & 14 & 1.1 \\
Novel Psychoactive Substances (i.e. piperazines) & \\
\hline Note: Piperazines were the only class of Novel Psychoactive Substances & 13 & 1.1 \\
present in this period. & & \\
\hline
\end{tabular}




\section{Table 6: Common combinations of substances implicated in UK SMR cocaine-related} DRDs 2005-9

\begin{tabular}{|c|c|c|}
\hline Substance combination & Number & $\%$ \\
\hline Alcohol \& heroin/morphine & 186 & 15.1 \\
\hline Alcohol \& any opiate/opioid & 229 & 18.6 \\
\hline Any opiate/opioid & 718 & 58.2 \\
\hline Any medication (exc. opiates/opioids) & 129 & 10.5 \\
\hline Any medication (exc. opiates/opioids) \& alcohol & 53 & 4.3 \\
\hline Any opiate/opioid \& drugs for anxiety/insomniahypnotics/sedatives & 182 & 14.7 \\
\hline Any opiate/opioid \& drugs for anxiety/insomniahypnotics/sedatives \& alcohol & 62 & 5.0 \\
\hline Any drugs for anxiety/insomniahypnotics/sedatives \& alcohol & 86 & 7.0 \\
\hline Any recreational drug (amphetamines, ecstasy, ketamine, GHB/GBL, NPS, etc.) & 137 & 11.1 \\
\hline Any recreational drug (amphetamines, ecstasy, ketamine, GHB/GBL, NPS, etc.) \& alcohol & 44 & 3.6 \\
\hline Amphetamines and/or ecstasy & 109 & 8.8 \\
\hline Amphetamines and/or ecstasy \& alcohol & 35 & 2.8 \\
\hline
\end{tabular}

Notes: $\mathrm{N}=1234$. Totals for individual categories should not be added together. 


\section{Table 7: Presence of contributing factors associated with cocaine mono-intoxication acute poisoning in UK SMR cases, 2005-9}

$36(13 \%)$ cases: pre-existing cardiovascular/cardiopulmonary conditions, which may lead to other complications and causes of death (e.g. ischaemic heart disease; coronary artery thrombosis; coronary thrombosis; thrombosis of left anterior descending coronary artery; coronary artery disease; coronary artery atheroma; myocardial fibrosis; hypertension; myocardial infarction; cardiomegaly; cardiomyopathy; left ventricular hypertrophy; left \& right ventricular hypotrophy; myocardial hypertrophy; dissecting aortic aneurysm; necrosis) $23(8 \%)$ cases: events possibly related to at-risk behaviours whilst on cocaine leading to external causes of death (e.g. immersion; head or multiple injuries i.e. road traffic accidents; hanging; cardio-respiratory arrest during restraint; intestinal obstruction in body-packers; toxicity in body-packers; mechanical obstruction of upper airway by foreign bodies => asphyxia)

$8(3 \%)$ cases: associated infections (e.g. bronchopneumonia; aspiration pneumonia; COPD; pneumonia; acute bronchitis; adult respiratory distress syndrome; myocarditis)

$8(3 \%)$ cases: pre-existing chronic medical conditions/natural disease (e.g. fatty liver change; alcohol liver disease; epilepsy/grand mal seizure; pulmonary hypertension \& Cor Pulmonale)

In $62(22 \%)$ cases, only cocaine and its well-known medical consequences were mentioned as the cause of death, including: myocardial infarction; cardio-respiratory failure/arrest, (acute) cardiac arrest/failure, sudden (cardiac) death; left ventricular failure; cardiac/ myocardial ischaemia/insufficiency; thromboembolism, thrombosis; myocardial damage, fibrosis; cardiac arrhythmia/disrhythmia; cerebral infarction, hypoxic brain damage/cerebral hypoxia, intracerebral haemorrhage; pulmonary oedema; pulmonary haemorrhage; aspiration of gastric contents/aspiration, asphyxia; pancreatitis; gastro-intestinal bleed/haemorrhage; renal failure.

154 (56\%) cases: cocaine intoxication, overdose, poisoning, toxicity, fatal misuse, etc.

Notes: $\mathrm{N}=277$. More than one condition can be recorded in the medical cause of death; therefore totals for individual categories should not be added together. Cocaine was the only drug mentioned in the cause of death. 